\title{
OPERATION OF EBR-II AS AN IRRADIATION FACILITY AT 62.5 MWt: \\ AN EVALUATION OF PLANT AND REACTOR DATA FROM RUN 46A
}

\author{
Coordinated by
}

R. A. Cushman
This report was prepared as an account of work sponsored by the United States Governmentic Energy the United States nor the United States Atomic nor any of Commission, nor any of their employees, nor any of their contractors, subcontractors, or the or assumes any makes any warranty, express or impled, accuracy, comlegal liability or responsibility for the accuracy, apparatus, pleteness or usefulness of any information, apparatus, product or process disclosed, or represents

\section{Major Contributors}
H. W. Buschman
L. B. Miller
R. A. Cushman
C. L. Nelson
I. A. Engen
W. H. Perry
H. A. Larson
C. C. Price
R. W. Hyndman
R. R. Smith
J. R. Karvinen
V. N. Thompson
F. S. Kirn
M. R. Tuck
$\mathrm{J}$. K. Long
W. R. Wallin

\author{
EBR-II Project \\ Argonne National Laboratory \\ Argonne, Illinois - Idaho Falls, Idaho
}

February 1971

Work performed under the auspices of the U. S. Atomic Energy Commission 


\section{DISCLAIMER}

This report was prepared as an account of work sponsored by an agency of the United States Government. Neither the United States Government nor any agency Thereof, nor any of their employees, makes any warranty, express or implied, or assumes any legal liability or responsibility for the accuracy, completeness, or usefulness of any information, apparatus, product, or process disclosed, or represents that its use would not infringe privately owned rights. Reference herein to any specific commercial product, process, or service by trade name, trademark, manufacturer, or otherwise does not necessarily constitute or imply its endorsement, recommendation, or favoring by the United States Government or any agency thereof. The views and opinions of authors expressed herein do not necessarily state or reflect those of the United States Government or any agency thereof. 


\section{DISCLAIMER}

Portions of this document may be illegible in electronic image products. Images are produced from the best available original document. 


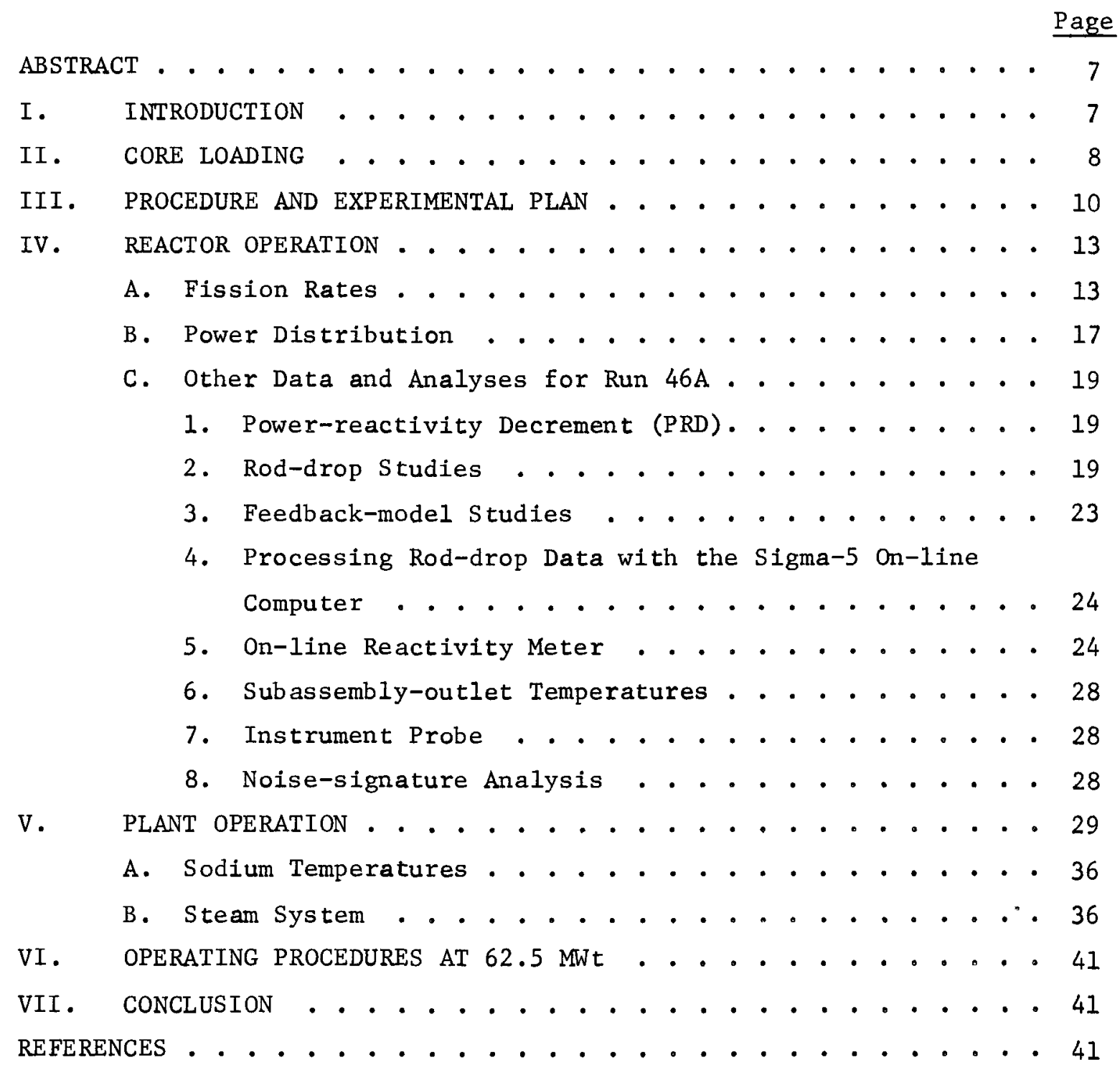


$\bullet$

• 


\section{LIST OF FIGURES}

No.

Title

$\underline{\text { Page }}$

1. Loading Pattern for EBR-II Run 46A . . . . . . . . . . . . 9

2. Radial Distribution of Relative Fission Rates in Driver-fuel Subassembly . . . . . . . . . . . . . . . . 16

3. Power-reactivity Decrement ( $P R D$ ) for Runs $38 \mathrm{~A}, 45 \mathrm{~A}$, and $46 \mathrm{~A}$ (curves offset for separate viewing) . . . . . . . . . 20

4. Power and Negative Feedback at 50 MWt at Start of Run 46A (average from five rod drops) . . . . . . . . . . 21

5. Power and Negative Feedback at 62.5 MWt at Start of Run 46A (average from four rod drops) . . . . . . . . . . . 22

6. Comparison of Measured 62.5-MWt Feedback with Feedback-reactivity Curve Calculated from 56-MWt Data; Start of Run 46A . . 25

7. Comparison of Feedback Function as Measured by Conventional and Sigma-5 Methods ..........。....... 26

8. Recordings made with On-line Reactivity Meter for Rod Drops at 50,56, and 62.5 MWt in Run 46A ........... 27

9. Noise Recording for Pump No. 1 (0 to $20 \mathrm{kHz}$ ) at $1500,9 / 29 / 70$. 30

10. Noise Recording for pump No. 1 (0 to $100 \mathrm{~Hz}$ ) 1515 to 1615 , 9/29/70 ....................... 31

11. Noise Recording for Pump No. 1 ( 0 to $20 \mathrm{kHz}$ ) at $1615,9 / 29 / 70.32$

12. Noise Recording for Pump No. 1 ( 0 to $20 \mathrm{kHz}$ ) at $2210,9 / 29 / 70$. 33

13. Noise Recording for Pump No。 $1(0$ to $100 \mathrm{~Hz}$ ) as a Function of Power, during Initial Rise to $62.5 \mathrm{MWt}$, Run 46A, 9/23/70 • 34

14. Noise Spectrum as a Function of Power for East Superheater . . 38

15. Noise Spectrum as a Function of Power for West Superheater . . 39 


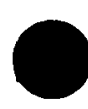

. 


\section{LIST OF TABLES}

No.

Title

Page

I. Experimental Subassemblies in EBR-II during Run 46A . . . . . 11

II. Comparison of Measured and Calculated Fission Rates for Run 46A . . . . . . . . . . . . . . . . . . 15

III. Absolute Fission Rate and Power-calibration Data . . . . . 15

IV. Fower Distribution (in $\mathrm{kW}$ ) per Standard Driver-fue1 Subassembly for Various Cores at $62.5 \mathrm{MWt}$. . . . . . . . . . 18

V. Heat Balances and Component Parameters for Runs $38 \mathrm{~A}$ and $46 \mathrm{~A} . \quad 35$ 
$\bullet$

\section{.} 年 


\title{
OPERATION OF EBR-II AS AN IRRADIATION FACILITY AT 62.5 MWt: AN EVALUATION OF PLANT AND REACTOR DATA FROM RUN 46A
}

\author{
Coordinated by
}

\author{
R. A. Cushman
}

\section{ABSTRACT}

\begin{abstract}
The initial operation of EBR-II at 62.5 MWt occurred during run 38A in September 1969, with a core containing no fueled experimental subassemblies. Run 38A indicated that the reactor and plant were capable of sustained operation at $62.5 \mathrm{MWt}$. After interim operation at $50 \mathrm{MWt}$, during which minor adjustments were made to the plant and experimenters were informed of the plan to operate continually at 62.5 MWt, run 46A was scheduled as the first to contain fueled experimental subassemblies and operate routinely at the higher power level. Experimental subassemblies were modified and relocated as required to match the higher-power conditions, and run $46 \mathrm{~A}$ was begun. The reactor and plant were monitored during the run, and several special tests were carried out. As a result of the tests, the recommendation is made to continue operation of EBR-II at $62.5 \mathrm{MWt}$.
\end{abstract}

\section{INTRODUCTION}

Since 1968 a continuous effort has been made to increase the operating power level of EBR-II to its design power of 62.5 MWt while the reactor fulfills its current primary role in the AEC'S LMFBR program as an irradiation facility and engineering test bed. In August, 1968, the reactor power was increased from the previous maximum operating level of 45 MWt to 50 MWt; in September,1969, according to $\mathrm{plan}^{1}$ a special core loading was installed in EBR-II and the power level was increased, during run 38A only, to 62.5 MWt. ${ }^{2}$ That operation indicated that the EBR-II reactor and power plant 
could perform at $62.5 \mathrm{MWt}$. A reduction in power to $50 \mathrm{MWt}$ was necessary while experimenters were informed of plans to proceed to routine operation at 62.5 MWt and existing experimental subassemblies were redesigned for those reactor conditions. Plans were then made for continual operation at 62.5 MWt, ${ }^{3}$ and such operation began on September 25, 1970. This report presents results of special tests and observations made during run 46A, the first of the routine runs at the design power of EBR-II.

\section{CORE LOADING}

The increase in power from 50 to $62.5 \mathrm{MWt}$ required that several experimental subassemblies, which were designed for operation in specific locations in the reactor at $50 \mathrm{MWt}$, be repositioned for 62.5-MWt operation. Some subassemblies required only relocating to a new core position farther from the reactor center. Other subassemblies, however, had to be removed from the reactor and disassembled, with the experimental elements being reconstituted in new subassemblies. Reconstitution of experimental subassemblies was required because the subassembly lower adapter is different for rows 1 through 5 than for rows 6 and 7 , as is the outer blanket adapter. The reconstitution posed no problem in accommodating the experiments in the reactor at higher power. There was, however, a scheduling difficulty, in that all of the experimental subassemblies being irradiated at $50 \mathrm{MWt}$ could not be reconstituted during the shutdown between runs 45 and 46 . Some of them were, therefore, removed and modified during run 45, while others were modified during run 46 and thus were not in the reactor during the initial increase in power with fueled experiments.

Therefore, the core loading for run 46, although it contained experimental subassemblies (in contrast to the initial 62.5-MWt operation during run 38A), was not a typical EBR-II loading. It contalned 20 experimental subassemblies. Run 44B, in contrast, contained 32 experimental subassemblies, and run $47 \mathrm{~B}$ is expected to contain 29. The actual core loading for run $46 \mathrm{~A}$ is shown in Fig. 1. It was an 88-subassembly core, with depleted-uranium blanket subassemblies in three row 6 positions for reactivity control. There were fueled experimental subassemblies in row 7 , and two of them (X058 and X062) contained sufficient fuel that depleted-uranium blanket 
KEY:

B - DEPLETED URANIUM

BETH - BERYLLIUM THIMBLE

C\# - CONTROL ROD

CF - CONTROLLED-FLOW SUBASSEMBLY

D - DRIVER FUEL

EBU - EXTENDED-BURAUP SUBASSEMBLYY

MK - II - MARK-1I FUEL
Mi - NICKEL-CORROSI ON SUBASSEMBLY

$P$ - $\frac{1}{2}$ DRIVER FUEL -- $\frac{1}{2}$ STAIMLESS STEEL

$R$ - STAINLESS STEEL REFLECTOR

SH - SAFETY ROD

SSCR - STAIMLESS STEEL CONTROL ROD

SSTH - STAINLESS STEEL THIMBLE

70\% - 70\% - ENRICHED DRIVER FUEL

$\square$ - EXPERIMENTAL SUBASSEMBLY

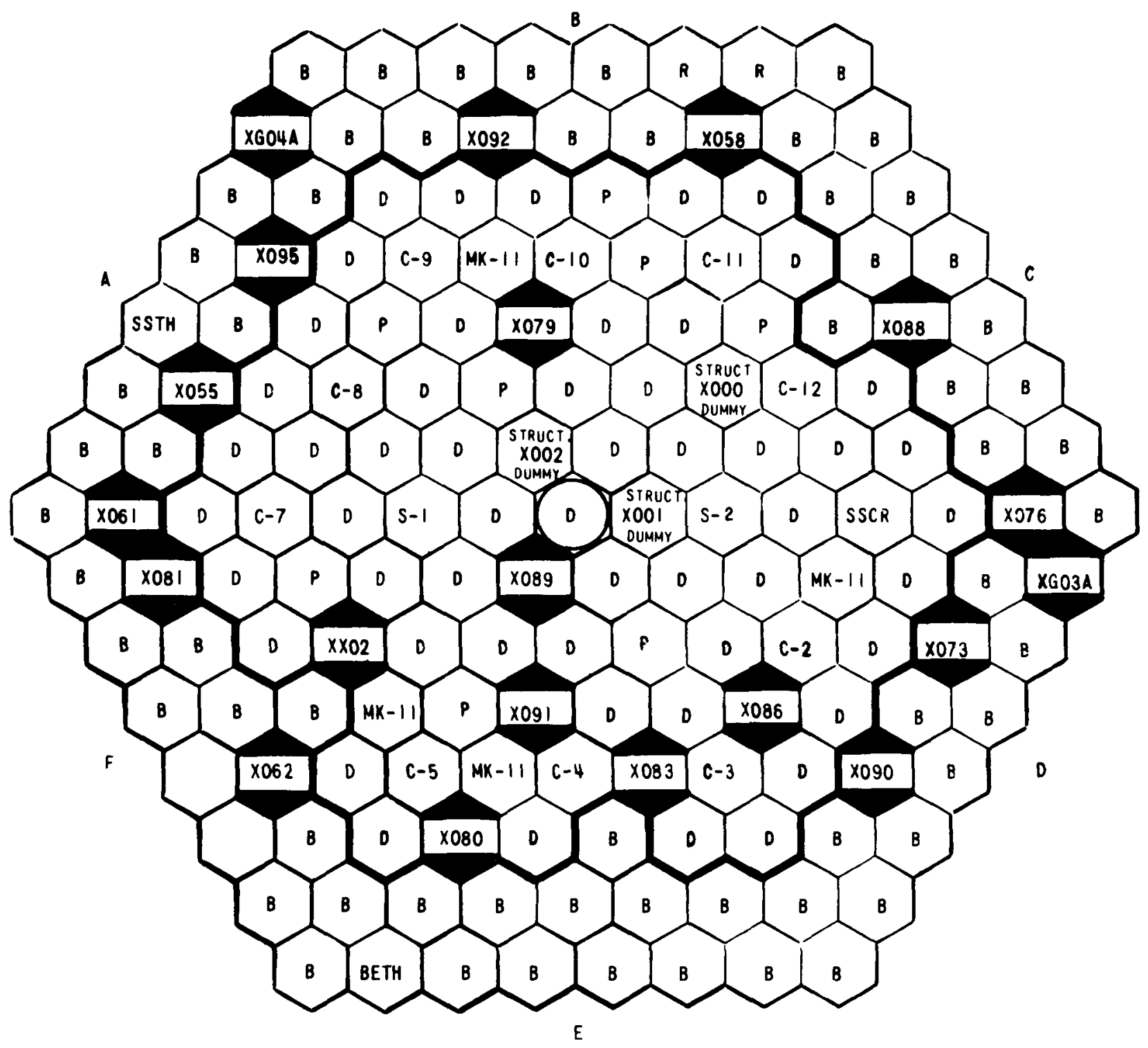

Fig. 1. Loading Pattern for EBR-II Run 46A 
subassemblies next to them in row 8 would have overheated. Two stainless steel reflector subassemblies, identical in appearance to the blanket subassemblies but containing solid stainless steel rods rather than uranium clad with stainless steel, were used in place of two depleted-uranium blanket subassemblies immediately outboard of each of the heavily fueled experimental subassemblies. Table I lists the experimental subassemblies that were loaded for run 46A, with pertinent information concerning them. Three dummy structural experimental subassemblies and nine half-worth subassemblies (containing 46 fuel elements and 45 stainless steel rods rather than 91 fuel elements) were loaded in the core for reactivity control and to simulate, in terms of loading, future experimental subassemblies. The stainless steel drop rod used in feedback analysis was in control-rod position 1 .

\section{PROCEDURE AND EXPERIMENTAL PLAN}

The generally successful completion of run 38A in September,1969, indicated that continual operation of the EBR-II reactor and plant at 62.5 MWt could commence as soon as the experimental subassemblies could be modified as required. There were, however, slight difficulties with some components (e.g., bypass steam valve) during run $38 \mathrm{~A}$, which were to be corrected during the interval. In addition, the run-46A core loading included fueled experiments, unlike that for run 38A. A test procedure was, therefore, prepared for run 46A: "Reactor and P1ant Systems Performance Test and Surveillance for Power Increase from $50 \mathrm{MWt}$ to $62.5 \mathrm{MWt}$ and Continued Operation at $62.5 \mathrm{MWt} . "$

The major specific areas covered by the test procedure, other than surveillance of plant conditions that changed owing to the higher-power operation, were:

1. A set of flux-wire irradiations at $50 \mathrm{kWt}$ to determine whether the fission-rate distribution for the revised core loading (experimental subassemblies moved generally farther from the core center) was similar to that for previous cores, as calculations had indicated;

2. Rod-drop measurements at zero power ( $500 \mathrm{kWt})$ and at 50,56 , and $62.5 \mathrm{MWt}$ for reactivity determinations; 
TABLE I. Experimental Subassemblies in EBR-II during Run 46A

\begin{tabular}{|c|c|c|c|c|c|}
\hline $\begin{array}{l}\text { Subassembly } \\
\text { Number and } \\
\text { (Position) } \\
\end{array}$ & $\begin{array}{c}\text { Date } \\
\text { Charged } \\
\end{array}$ & $\begin{array}{l}\text { Capsule Content } \\
\text { (Number of Caps }\end{array}$ & & Experimenter & Reconstituted \\
\hline $\begin{array}{l}\mathrm{XX02} \\
(5 \mathrm{~F} 3)\end{array}$ & $4 / 13 / 70$ & $\mathrm{UO}_{2}-25$ wt $\% \mathrm{PuO}_{2}$ & $(36)$ & HEDL & No \\
\hline $\begin{array}{l}\text { XG03A } \\
(8 \mathrm{D} 2)\end{array}$ & $9 / 14 / 70$ & $\mathrm{UO}_{2}-20$ wt $\% \mathrm{PuO}_{2}$ & (2) & GE & Yes \\
\hline $\begin{array}{l}\mathrm{XG04A} \\
(8 \mathrm{~A} 7)\end{array}$ & $9 / 15 / 70$ & $\mathrm{UO}_{2}-20$ wt $\% \mathrm{PuO}_{2}$ & (2) & GE & No \\
\hline $\begin{array}{l}\mathrm{X} 055 \\
(7 \mathrm{~A} 3)\end{array}$ & $2 / 23 / 69$ & $\left(\mathrm{U}_{0.85^{-P u_{0.15}}}\right) \mathrm{C}$ & (19) & UNC & No \\
\hline $\begin{array}{l}\mathrm{x} 058 \\
(7 \mathrm{~B} 6)\end{array}$ & $4 / 24 / 69$ & $\mathrm{UO}_{2}-25$ wt $\% \mathrm{PuO}_{2}$ & (37) & $\mathrm{GE}$ & No \\
\hline $\begin{array}{l}\mathrm{X} 061 \\
(7 \mathrm{Al})\end{array}$ & $4 / 23 / 69$ & Structural & (7) & INC & No \\
\hline $\begin{array}{l}\mathrm{X} 062 \\
(7 \mathrm{~F} 3)\end{array}$ & $5 / 23 / 69$ & $\mathrm{UO}_{2}-25$ wt $\% \mathrm{PuO}_{2}$ & (37) & GE & No \\
\hline $\begin{array}{l}\mathrm{X} 073 \\
(7 \mathrm{D} 3)\end{array}$ & $12 / 12 / 69$ & $\mathrm{UO}_{2}-25 \mathrm{wt} \% \mathrm{PuO}_{2}$ & (37) & HEDL & No \\
\hline $\begin{array}{l}\mathrm{X} 076 \\
(7 \mathrm{D} 1)\end{array}$ & $3 / 27 / 70$ & $\mathrm{UO}_{2}-25$ wt $\% \mathrm{PuO}_{2}$ & (19) & WARD & No \\
\hline $\begin{array}{l}\mathrm{X} 079 \\
(4 \mathrm{~B} 2)\end{array}$ & $4 / 17 / 70$ & $\left(\mathrm{U}_{0.85^{-P u_{0.15}}}\right) \mathrm{C}$ & (19) & UNC & No \\
\hline $\begin{array}{l}\mathrm{X} 080 \\
(6 \mathrm{E} 5)\end{array}$ & $9 / 11 / 70$ & $\begin{array}{l}\mathrm{UO}_{2}-20 \text { wt } \% \mathrm{PuO}_{2} \\
\text { Structural } \\
\text { Structural }\end{array}$ & $\begin{array}{r}(12) \\
(1) \\
(4)\end{array}$ & $\begin{array}{l}\text { NUMEC/ANL } \\
\text { GE } \\
\text { GE }\end{array}$ & No \\
\hline $\begin{array}{l}\mathrm{X} 081 \\
(7 \mathrm{~F} 6)\end{array}$ & $5 / 24 / 70$ & $\mathrm{UO}_{2}-25$ wt $\% \mathrm{PuO}_{2}$ & (9) & GE & No \\
\hline $\begin{array}{l}\mathrm{X} 083 \\
(5 E 2)\end{array}$ & $9 / 15 / 70$ & Mark-IA fuel & $(61)$ & ANL & No \\
\hline $\begin{array}{l}\mathrm{X} 086 \\
(5 E 2)\end{array}$ & $8 / 7 / 70$ & 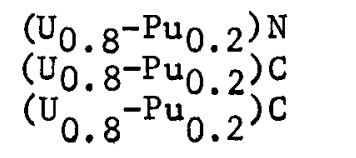 & $\begin{array}{r}(10) \\
(5) \\
(4)\end{array}$ & $\begin{array}{l}\text { BMI } \\
\text { LASL } \\
\text { WARD }\end{array}$ & No \\
\hline $\begin{array}{l}x 088 \\
(7 C 4)\end{array}$ & $5 / 24 / 70$ & $\mathrm{UO}_{2}-25$ wt $\% \mathrm{PuO}_{2}$ & (19) & WARD & No \\
\hline
\end{tabular}


Table I (contd)

\begin{tabular}{|c|c|c|c|c|c|}
\hline $\begin{array}{l}\text { Subassembly } \\
\text { Number and } \\
\text { (Position) } \\
\end{array}$ & $\begin{array}{c}\text { Date } \\
\text { Charged } \\
\end{array}$ & $\begin{array}{l}\text { Capsule C } \\
\text { (Number of }\end{array}$ & & Experimenter & Reconstituted \\
\hline $\begin{array}{l}\mathrm{X} 089 \\
(2 \mathrm{~F} 1)\end{array}$ & $9 / 15 / 70$ & Structural & (7) & HEDL & No \\
\hline $\begin{array}{l}\text { X090 } \\
\text { (7D5) }\end{array}$ & $9 / 15 / 70$ & $\begin{array}{l}\text { Structural } \\
\text { Structural } \\
\text { Structural } \\
\text { Structural }\end{array}$ & $\begin{array}{l}(4) \\
(1) \\
(1) \\
(1)\end{array}$ & $\begin{array}{l}\text { BMI } \\
\text { INC } \\
\text { ORNL } \\
\text { HEDL }\end{array}$ & No \\
\hline $\begin{array}{l}\mathrm{X} 091 \\
(4 E 3)\end{array}$ & $9 / 11 / 70$ & Structural & (7) & HEDL & No \\
\hline $\begin{array}{l}\text { X092 } \\
\text { (7B3) }\end{array}$ & $9 / 15 / 70$ & Structural & (1) & LASL & No \\
\hline $\begin{array}{l}\times 095 \\
(7 A 5)\end{array}$ & $9 / 18 / 70$ & Structural & (1) & NRL & No \\
\hline
\end{tabular}


3. Determinations of power-reactivity decrements up to $62.5 \mathrm{MWt}$ with the new core loading;

4. Acoustic-noise recordings of the sodium-to-superheated-steam heat exchanger, to determine the effect, if any, of a higher rate of flow of secondary sodium at higher power, and similar recordings of the primary pumps to obtain an operating signature of these pumps; and

5. Determination of the effects of improvements in the plant system made since run $38 \mathrm{~A}$. Three specific changes were made:

\section{a. Large Steam Bypass Valve (P3-VC-501A)}

The pneumatic controls for the valve were replaced with electronic components. This change has greatly reduced the lag time of the system. A new "V-pup" plug was installed in the valve.

b. Turbine-driven Feedwater Pump

The turbine-driven feedwater pump was overhauled after run $38 \mathrm{~A}$. In addition, the discharge check valve of the motor-driven pump was not tightly closed during run 38A. A damaged seat ring prevented the disk from seating, and thus allowed backflow through the turbine-driven pump so that its capacity was decreased. The check valve has been repaired, and a stepwise improvement was noted in the performance of the turbinedriven pump at 50 MWt.

\section{c. $13.8 \mathrm{kV}-480 \mathrm{~V}$ Transformers}

Cooling fans have been installed on the two $13.8 \mathrm{kV}-480 \mathrm{~V}$ transformers. This installation has increased the capacity of each transformer from 2000 to $2300 \mathrm{kVA}$, so that either transformer can handle the entire load if the other should fail.

\section{REACTOR OPERATION}

\section{A. Fission Rates}

Run $46 \mathrm{~A}$ began, as planned, with irradiation at $50 \mathrm{kWt}$ of uraniumwire detectors. Extensive calculations had been made before run 46 to give confidence that the experimental subassemblies could be relocated without compromising the relative heat ratings. However, because of the many changes, this 
confidence was verified with measured fission rates. Consequently, three special wire subassemblies were loaded into the reactor in positions $1 \mathrm{Al}$, $5 \mathrm{~A} 2$, and 6D3. Two ${ }^{235} \mathrm{U}$-wire detectors were placed in each subassembly, and one ${ }^{238_{U}}$-wire detector was placed in position $1 A 1$ and two in 6D3. These samples, all at the axial midplane, were irradiated for 1 hr at an estimated $50 \mathrm{~kW}$. The measured relative fission rates in ${ }^{235} \mathrm{U}$ are compared with calculated values in Table II. The calculated values were obtained from both DOT $X-Y$ problems and from the BURNUP code for the run-46A loading.

It was concluded from these data that, within the core region of the reactor, the relative flux distribution would be adequately described by the distribution used for the runs before the loading changes, until the extensive fission-rate map is determined during run 49 or 50 .

In addition to the relative fission rates, absolute fission rates were obtained for the central subassembly. Table III lists the results from this measurement. From Table III, a calibration of power can be made by using the same relative fission rate-distribution normally used in the BURNUP code.

Estimates from the above data indicate the test was run at an equivalent of $46.7 \mathrm{~kW}$. From the thermal calibration at $50 \mathrm{MWt}$ and the ratio of the channel-7 data of TableIII, the power level was estimated at $49.2 \mathrm{~kW}$. This ratio of 0.95 for the two estimates further confirms previous findings that the ratio of burnup rates measured from fission-product determination to those of the EBR-II BURNUP code is 0.95 .

Curves showing the relative radial fission rate for several cores, including the measured values obtained with the run-29D loading, were given in Fig. 2 of Ref. 3. This figure is reproduced here as Fig. 2, but superimposed on the figure is the local/average fission-density distribution for the run-46A core loading. The distribution is, as can be seen from Fig. 2, similar to all of the projected 62.5-MWt cores with experimental subassemblies, as well as that measured for run 29D. The curve for run 46A, as for the other calculated curves, was obtained by taking the average fission rate for all driver-fuel subassemblies in a given type of core position (e.g., $3 \mathrm{~N} 2,5 \mathrm{~N} 2$ ) as calculated by the POWER subroutine of the DOT $\mathrm{X}-\mathrm{Y}$ problem for the given core loading. 
TABLE II. Comparison of Measured and Calculated Fission Rates for Run 46A

\begin{tabular}{|c|c|c|c|c|c|c|c|c|}
\hline \multirow[b]{2}{*}{$\begin{array}{l}\text { Subassembly } \\
\text { Position } \\
\end{array}$} & \multirow[b]{2}{*}{$\begin{array}{c}\text { Foil } \\
\text { Number }\end{array}$} & \multirow[b]{2}{*}{$\begin{array}{l}\text { Radius, } \\
\mathrm{cm} \\
\end{array}$} & \multicolumn{4}{|c|}{$\begin{array}{c}{ }^{235} \text { U Fission Rate } \\
\text { (Relative) }\end{array}$} & \multicolumn{2}{|c|}{ Ratios } \\
\hline & & & \multicolumn{2}{|c|}{ Measured } & \multirow[t]{2}{*}{ DOT-5 } & \multirow{2}{*}{$\frac{\text { BURNUP }}{1.00}$} & $\frac{\text { DOT-5 }}{\text { Measured }}$ & $\frac{\text { BURNuP }}{\text { Measured }}$ \\
\hline \multirow[t]{3}{*}{$1 \mathrm{~A} 1$} & 2 & 2.6 & & 1.00 & & & & \\
\hline & 3 & 2.6 & & 0.982 & & 1.00 & & \\
\hline & & & avg & 0.99 & 1.00 & 1.00 & 1.01 & 1.01 \\
\hline \multirow[t]{3}{*}{$5 \mathrm{~A} 2$} & 2 & 19.1 & & 0.846 & & 0.834 & & 0.99 \\
\hline & 4 & 23.4 & & 0.758 & & 0.743 & & 0.98 \\
\hline & & & avg & 0.802 & 0.818 & 0.789 & 1.02 & 0.98 \\
\hline \multirow[t]{3}{*}{ 6D3 } & 4 & 23.8 & & 0.741 & & 0.705 & & 0.95 \\
\hline & 2 & 27.7 & & 0.649 & & 0.607 & & 0.94 \\
\hline & & & avg & 0.695 & 0.647 & 0.656 & 0.93 & 0.94 \\
\hline
\end{tabular}

$a_{\text {Geometric center. }}$

TABLE III. Absolute Fission Rate and Power-calibration Data
Total fission ${ }^{235} \mathrm{U}$, fissions/g $235_{\mathrm{U}}$
$0.292 \times 10^{13}$
Total fission ${ }^{238} \mathrm{U}$, fissions/g $238_{\mathrm{U}}$
$0.187 \times 10^{12}$
Length of run, sec
3650
Channe1-7 reading, $A$
$48.1 \% \times 10^{-7}$
Channel-7 reading @ $50 \mathrm{MWt}$, A
$48.9 \% \times 10^{-4}$
BURNUP code normalization, fissions/g
- MWd @ $200 \mathrm{MeV} /$ fission (central
$1.51 \times 10^{16}$

fission rate) 


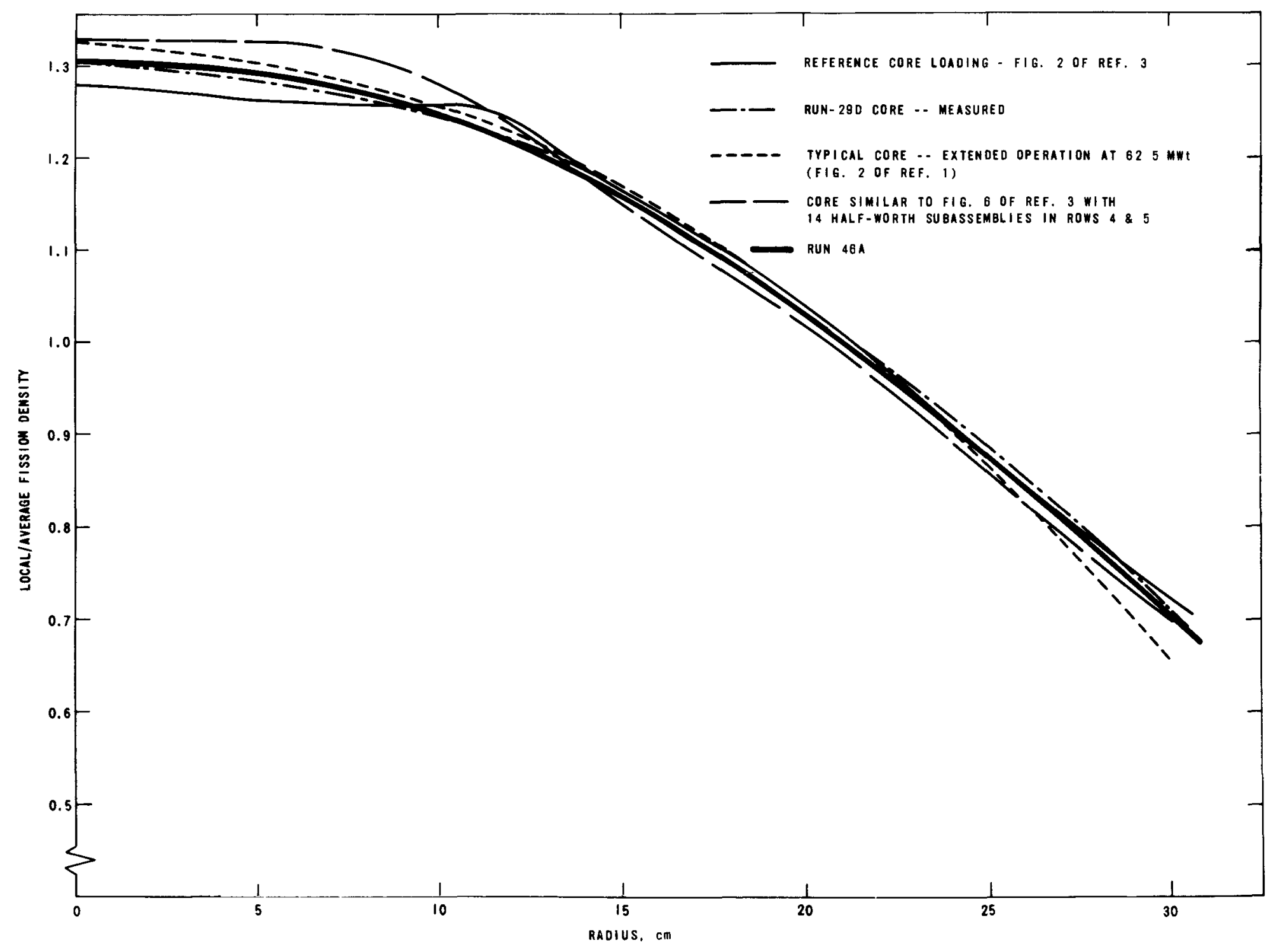

Fig. 2. Radial Distribution of Relative Fission Rates in Driver-fuel Subassembly 


\section{B. Power Distribution}

Because the radial fission-rate distribution for the run- $46 \mathrm{~A}$ core was so similar to that for similar projected 62.5-MWt core loadings with experimental subassemblies, the actual power distribution among subassemblies was also similar to projected cases. This similarity is shown in Table IV, which reproduces $\mathrm{Table} I$ from Ref. 3, with the addition of a column of subassembly powers for run 46A. The power per driver-fuel subassembly for the actual loading, with the exception of rows 1 and 2 (which are off by less than $1 \%$ ), lies between values projected for the cores presented in the proposals for 62.5-MWt operation (Refs. 1 and 3). Each value in Table IV is the power produced in a standard EBR-II Mark-IA driver-fuel subassembly if it were placed in the particular location in the given core. (There may not always be a standard driver-fuel subassembly in a given position; e.g., 5N1 and 5N3 normally contain control-rod subassemblies, and any 10cation could contain an experimental subassembly.) Also shown in Table IV is the number of effective driver-fuel subassemblies that constitute the given core. An effective driver-fuel subassembly is one that corresponds in power density to a standard one. A safety rod, for instance, is $61 / 91$ of an effective driver-fuel subassembly.

The first column in Table IV (after that for core position) is for the actual run-46A core. The second is for the reference loading for 62.5-MWt operation with experimental subassemblies, from Ref. 3. The third column is for the extended-operation core,from Ref. 1. The last two columns present data relevant to the all-driver-fuel core originally analyzed for 62.5-MWt operation. The fourth column gives data from ANL-5719 (Addendum). The last column gives corresponding results for the all-driver-fuel core with the same core loading and fission distribution as in ANL-5719 (Addendum), with temperatures calculated by current methods uttlizing the POWDIST program. The last two columns show the significant effect of core size on power distribution and peak power density by comparison with the first two columns. The increase in the number of effective subassemblies in a 91subassembly core over that analyzed in ANL-5719 (Addendum) assures that the power density must decrease to less than that of the original configuration. Small changes in further irradiation loadings at 62.5 MWt will not significantly affect the subassembly temperature distributions. 
TABLE IV. Power Distribution (in $\mathrm{kW}$ ) per Standard Driver-fuel Subassembly for Various Cores at 62.5 MWt

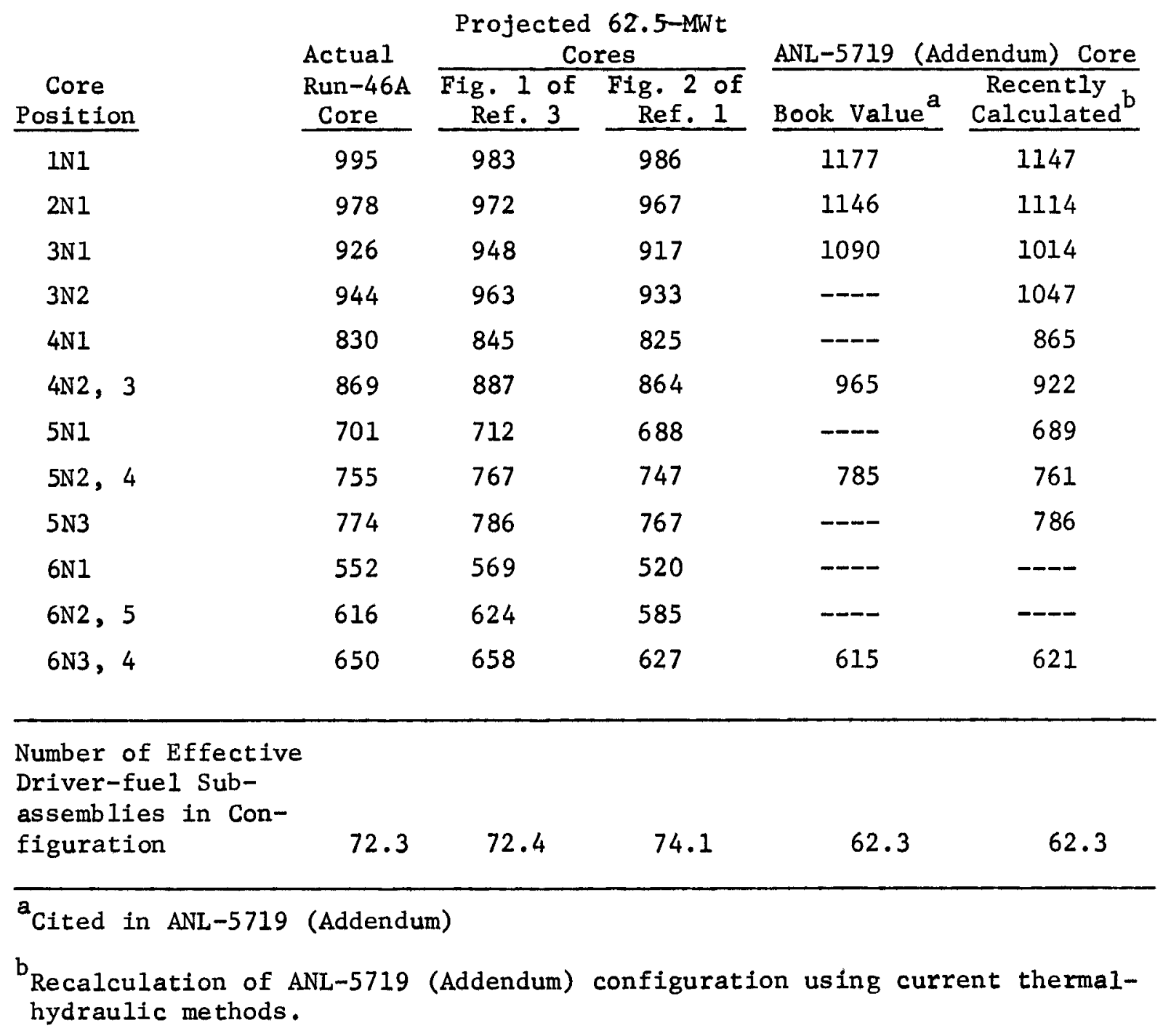




\section{Other Data and Analyses for Run 46A}

Information concerning the power-reactivity decrement ( $P R D)$, roddrop studies, feedback-model studies, the use of the Sigma-5 on-line computer to process rod-drop data, the on-line reactivity meter, subassemblyoutlet temperatures, the instrument probe, and noise-signature analysis was obtained for run $46 \mathrm{~A}$. This information is given below.

\section{Power-reactivity Decrement (PRD)}

Power-coefficient measurements were made at approximate 10-MWt increments during the ascent to $62.5 \mathrm{MWt}$ at the start of run $46 \mathrm{~A}$ and during the shutdown at the end of run 46A. Figure 3 compares the data from these measurements with data taken during runs $45 \mathrm{~A}$ and $38 \mathrm{~A}$. (For Run $38 \mathrm{~A}$, see Introduction.)

The slight upward bend between 50 and 62.5 MWt in the $P R D$ curve for run 38A is also apparent in the curve for run 46A. This effect is believed to have originated from an increase in the fraction of fuel material entering the gamma phase at the higher temperatures associated with 62.5-MWt operation.

\section{Rod-drop Studies}

The reactor was started up and brought to a power level of 50 MWt on September 21. After a series of rod drops at $50 \mathrm{MWt}$, the power level was reduced to $500 \mathrm{kWt}$ to calibrate the reactivity worth of the drop rod. Additional rod drops were made and the power level again was increased to $50 \mathrm{MWt}$. Rod drops were repeated at $50 \mathrm{MWt}$, and the resulting feedback data were used to predict the feedback at $56 \mathrm{MWt}$. Then the power level was increased to $56 \mathrm{MWt}$, additional rod drops were made, and the resulting feedback data were used to predict the feedback at 62.5 MWt. The power level was increased to the goal of 62.5 MWt on September 25, and rod-drop measurements were repeated at this power level.

Typical rod-drop data are shown in Figs. 4 and 5 , which give the power and computed feedback recovery at 50 and $62.5 \mathrm{MWt}$, respectively. 


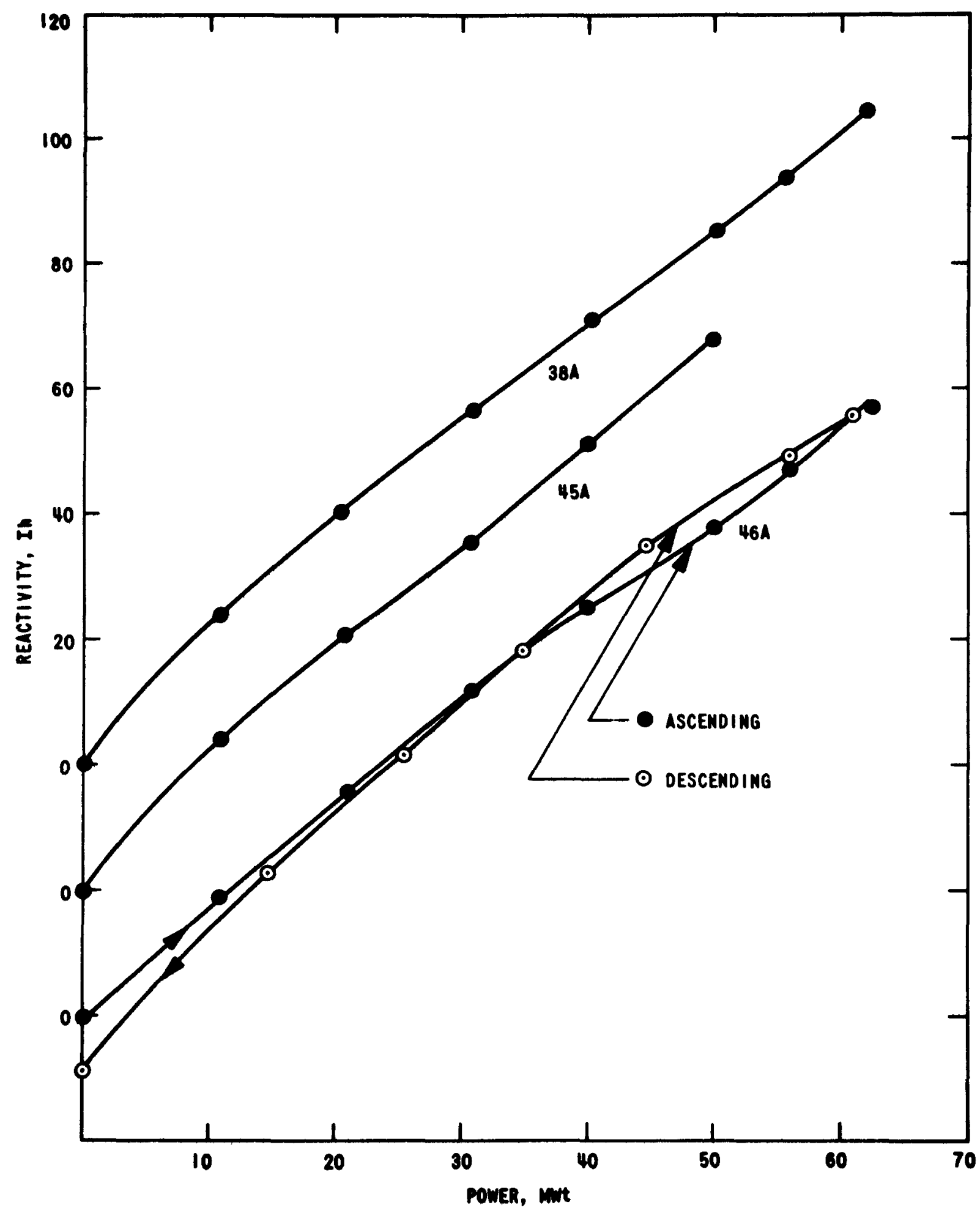

Fig. 3. Power-reactivity Decrement (PRD) for Runs 38A, 45A, and 46A (curves offset for separate viewing) 


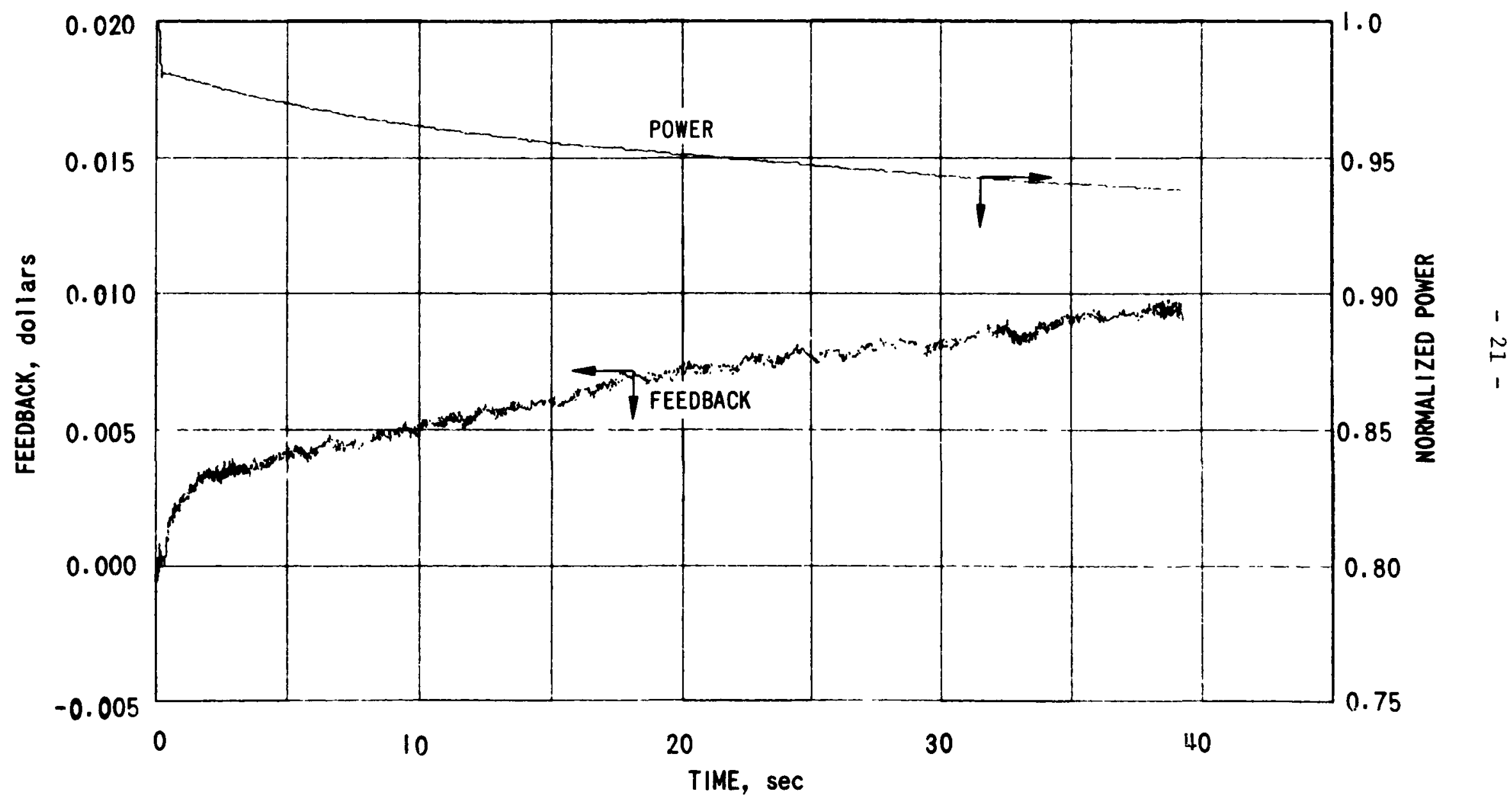

Fig. 4. Power and Negative Feedback at $50 \mathrm{MWt}$ at Start of Run 46A (average from five rod drops) 


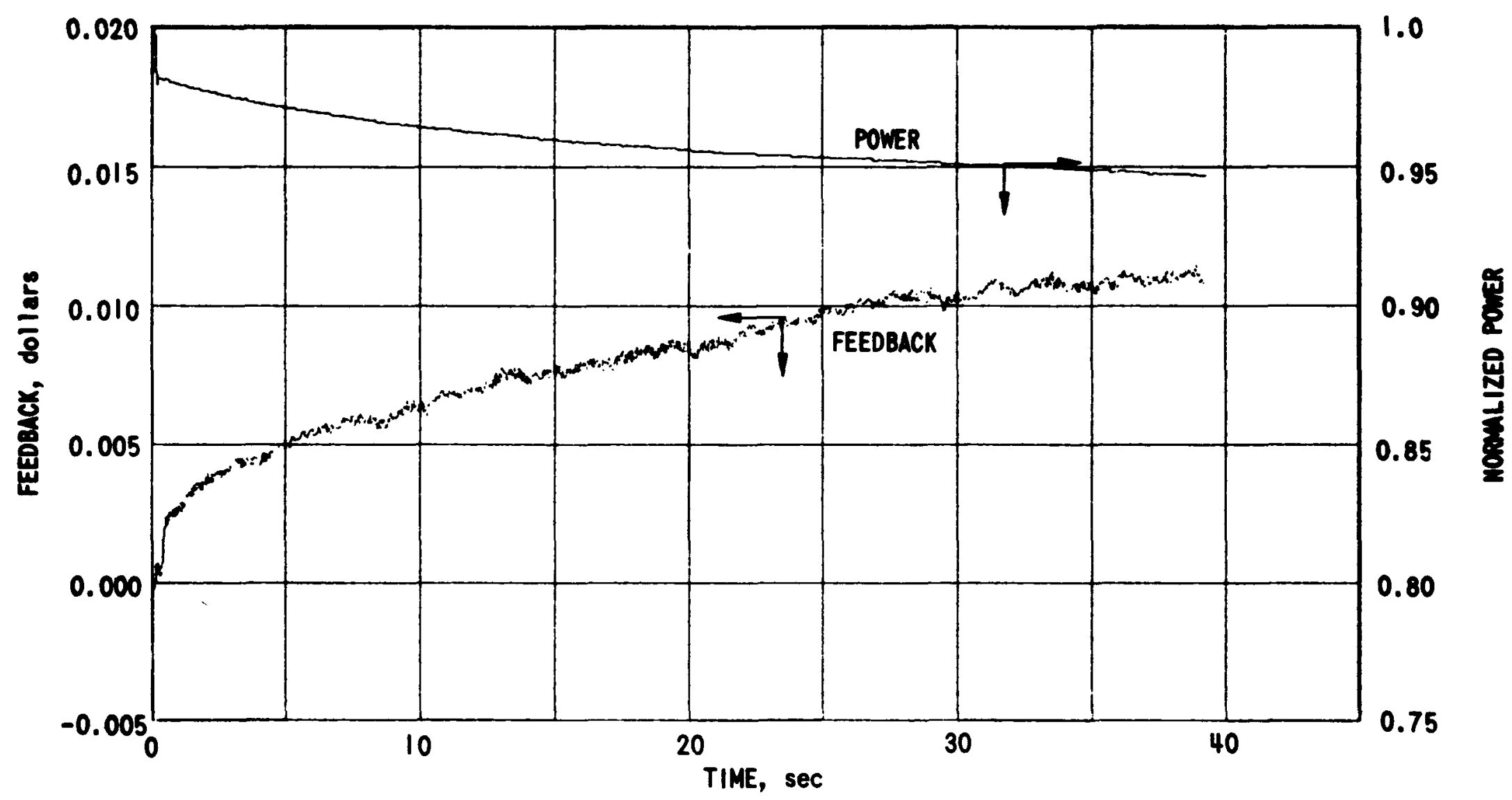

Fig. 5. Power and Negative Feedback at 62.5 MWt at Start of Run 46A (average from four rod drops) 
At both powers, the feedback is negative and is prompt in the time interval 0-2 sec after the drop. Similar data sets (not illustrated) were taken over the power range from 62.5 to $40.0 \mathrm{MWt}$ at the end of run $46 \mathrm{~A}$. Reference 4 contains a detailed analysis of the rod-drop experiments.

\section{Feedback-mode1 Studies}

As cited in the preceding section, the feedback measured at $50 \mathrm{MWt}$ was used to predict the feedback at $56 \mathrm{MWt}$. Similarly, the feedback measured at $56 \mathrm{MWt}$ was used to predict that at $62.5 \mathrm{MWt}$. The method involved the fitting of feedback data to a mathematical model in the manner described by Hyndman and Nicholson. 5 Then, the coefficients (amplitudes) of each feedback term in the model were increased by the ratio of the power increase, and the feedback-recovery function was recomputed. Power was increased to the next level, and the measured feedback was compared with the predicted feedback.

The models, which incorporate the best-fit values for amplitudes and time constants, were as follows:

Power Level, MWt

Feedback Model

50

56

$$
\begin{aligned}
& -H(S)=\frac{0.1}{1+0.2 \mathrm{~S}}+\frac{0.048}{1+0.4 \mathrm{~S}}-\frac{0.018}{1+2.0 \mathrm{~S}} \\
& -H(S)=\frac{0.085}{1+0.2 \mathrm{~S}}+\frac{0.0312}{1+0.4 \mathrm{~S}}+\frac{0.037}{1+2.0 \mathrm{~S}}+\frac{0.0341 \mathrm{e}^{-5.0 \mathrm{~S}}}{1+5.4 \mathrm{~S}} \\
& -\mathrm{H}(\mathrm{S})=\frac{0.095}{1+0.2 \mathrm{~S}}+\frac{0.0335}{1+0.4 \mathrm{~S}}+\frac{0.051}{1+2.0 \mathrm{~S}}+\frac{0.020 \mathrm{e}^{-5.0 \mathrm{~S}}}{1+5.4 \mathrm{~S}}
\end{aligned}
$$

The amplitudes in these models are expressed in units of dollars of reactivity and are defined as the product of the power level (in megawatts) and the differential power coefficient of reactivity (in dollars of reactivity per megawatt). The feedback, $-\mathrm{H}$, is a complex number and is expressed in dollars of reactivity. $S$ is the complex operator, $i \omega$, where $w$ is oscillation frequency in radians/sec. Hence, when $S=0$ (i.e., when the reactor is operating under steady-state conditions), $-\mathrm{H}$ defines the $\mathrm{PRD}$ 
(power-reactivity decrement), which is the amount of reactivity required to bring the system from hot critical to the power level at which the measurements were made.

In the models, a positive amplitude defines a negative feedback effect. Similarly, a negative amplitude indicates a positive feedback effect.

If feedback effects in the range of 50-62.5 MWt were truly linear, a simple multiplication of the amplitude for the 50-MWt model by the factor $62.5 / 50$ should give the amplitudes measured at $62.5 \mathrm{MWt}$. An inspection of the values in the models, however, shows that the feedback over the range of 50-62.5 MWt is not strictly linear. On the other hand, multiplication of the amplitudes for the 56-MWt model by the factor 62.5/56 does give reasonable predictions of the 62.5-MWt feedback function. Figure 6 compares the measured data with those calculated from the model given in the figure.

\section{Processing Rod-drop Data with the Sigma-5 On-line Computer}

Two methods were used for processing rod-drop data during run 46A. One was the conventional method, which uses the IBM-1620 and IBM-360/75 computers. The other method used the recently installed Sigma-5 dataprocessing system, otherwise known as the digital data-acquisition system (DAS), ${ }^{6}$ supplied by Xerox Data Systems.

Figure 7 compares rod-drop feedback data processed by the two methods. The continuous curve for feedback was derived from an analysis made in the conventional manner. The open circles are values derived from the Sigma-5 analysis. The agreement is excellent, as it was with all other rod-drop data processed by the two methods during run 46A. This excellent agreement indicates that the Sigma-5 system is operational for on-line processing of rod-drop data. (The data presented in Figs. 4 and 5 were processed with the Sigma-5 system.)

\section{On-line Reactivity Meter}

Figure 8 shows reactivity-meter recordings for rod drops at 50, 56, and 62.5 MWt. Apparent is the negative-feedback recovery in the first 


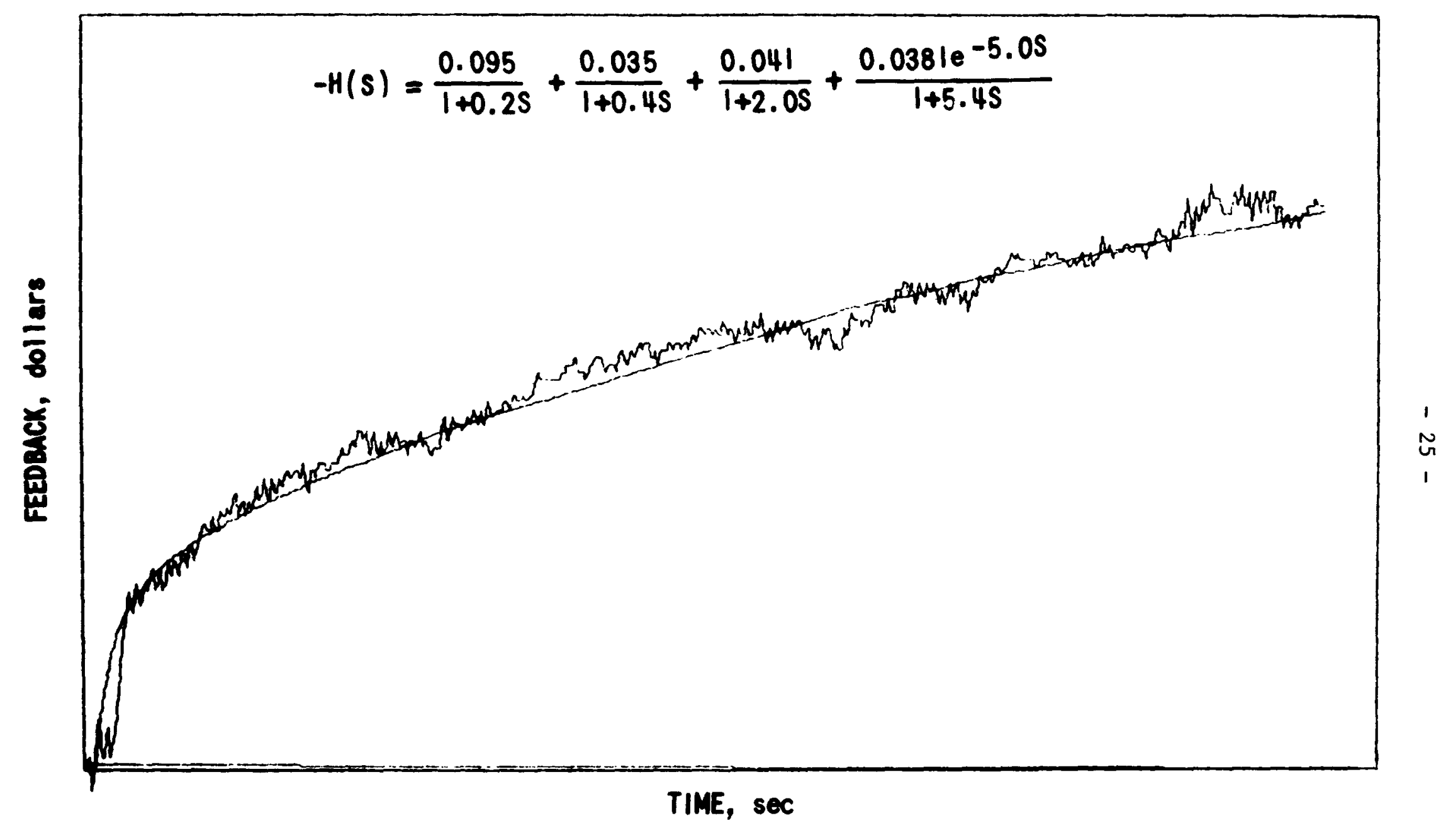

Fig. 6. Comparison of Measured 62.5-MWt Feedback with Feedback-reactivity Curve Calculated from 56-MWt Data; Start of Run 46A 


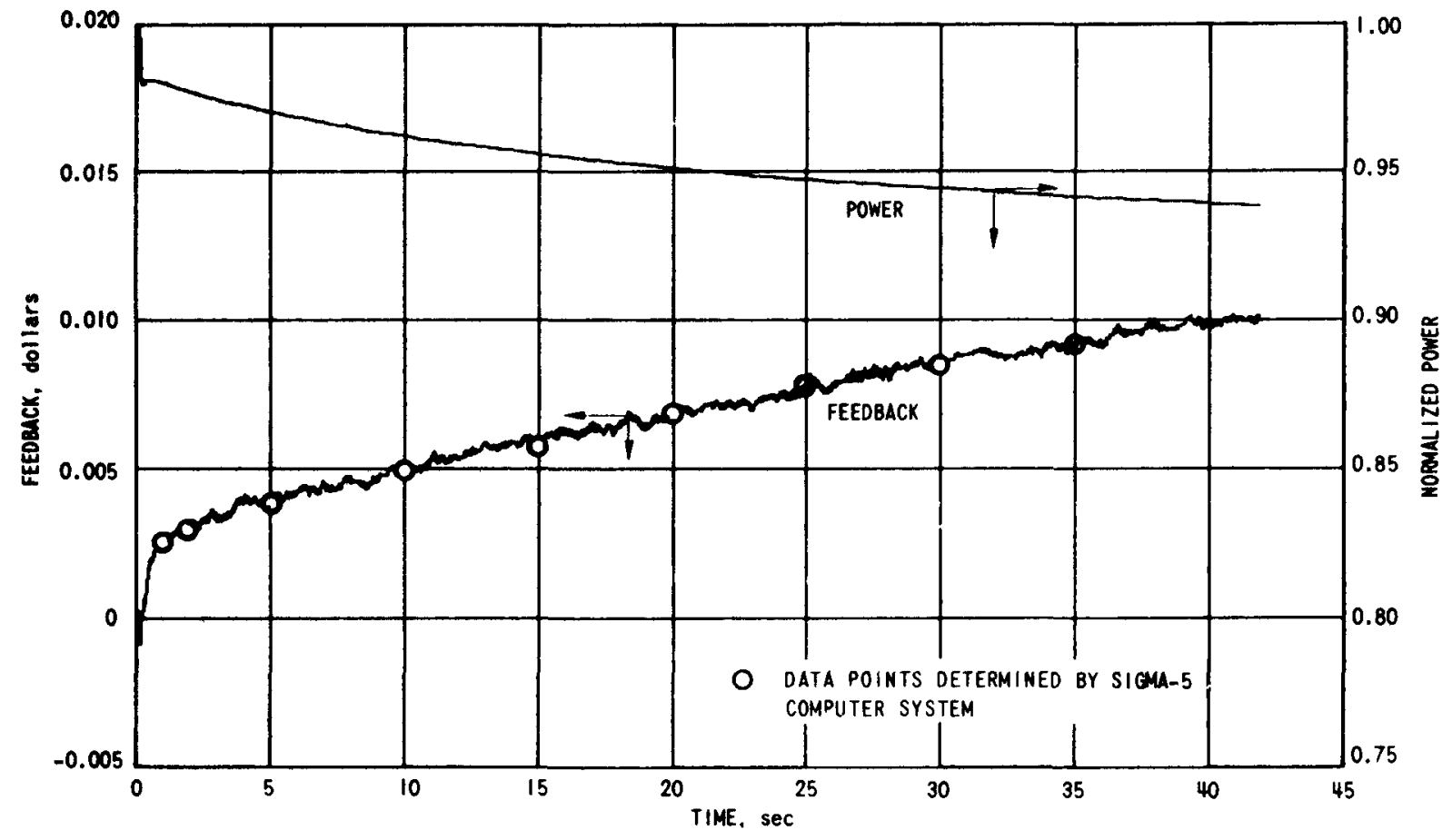

Fig. 7. Comparison of Feedback Function as Measured by Conventional and Sigma-5 Methods 


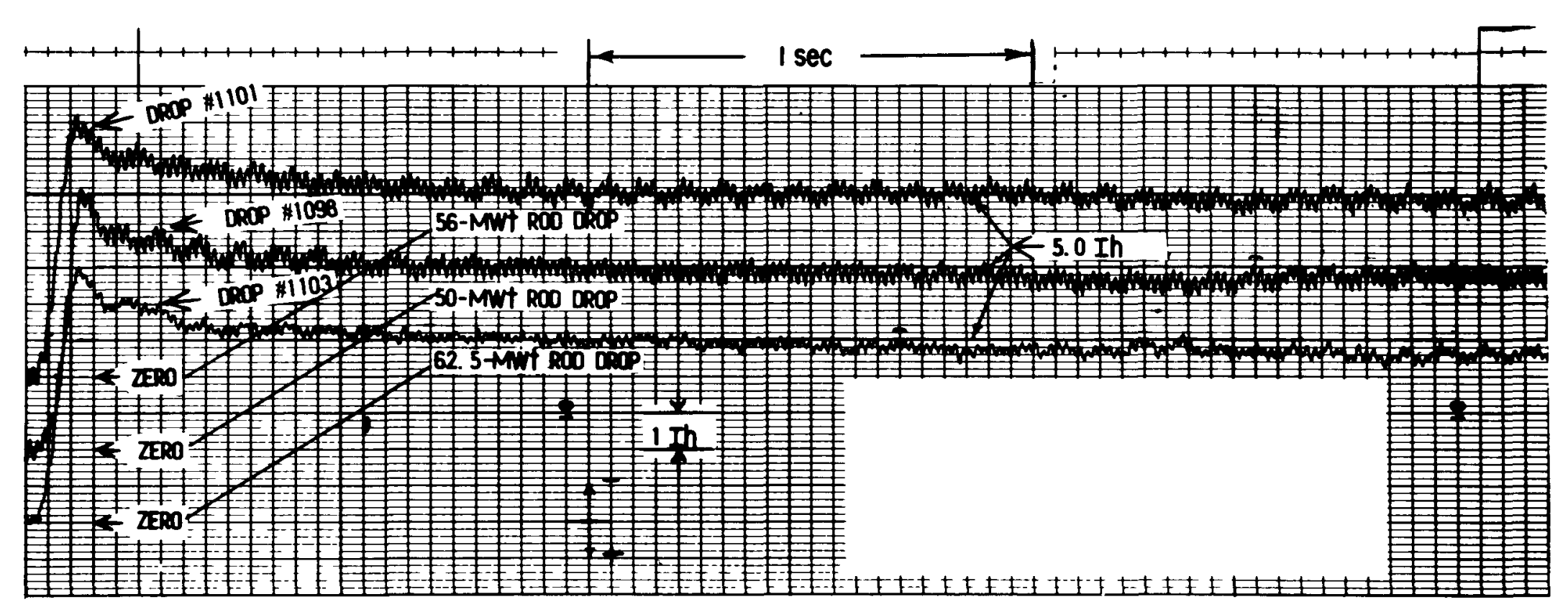

Fig. 8. Recordings made with On-line Reactivity Meter for Rod Drops at 50, 56, and 62.5 MWt in Run 46A 
few tenths of a second after the drop. The feedback recovery had essentially the same time dependence as that established with the inversekinetics program. This fact suggests that the output of the reactivity meter may be used for rapid assessment of the operative feedback.

\section{Subassembly-outlet Temperatures}

Subassembly-outlet temperatures increased linearly with power during the power increase. Small deviations from expected values were noted, but these were of the same order as those usually noted.

\section{Instrument Probe}

During run $46 \mathrm{~A}$, the temperature distribution of coolant in the reactor outlet plenum was measured at a radius corresponding to a row-14 blanket position. Average temperatures recorded (beginning with the lowest thermocouple) were $882,878,871,910,925,902$, and $896^{\circ} \mathrm{F}$. During run $38 \mathrm{~A}$ in September 1969, corresponding temperatures were $853,854,858,878$, 881,880 , and $880^{\circ} \mathrm{F}$. The small differences are believed caused by a change in the flow pattern in the plenum, which was caused by differences in the core loadings. The relationship between the pressure in the upper plenum (as indicated by pressure-sensing equipment on the probe) and flow rate did not change.

\section{Noise-signature Analysis}

Noise patterns were established for the neutron level and the two primary-sodium pumps at each steady-state power step in the ascent to 62.5 MWt. Figure 8 shows that a considerable 10-Hz noise component (in the neutron level) existed, particularly at 50 and 56: MWt. Also apparent in the figure is the indication that the amplitude of the 10-Hz noise decreased after the power level was raised to $62.5 \mathrm{MWt}$. As run 46A progressed, the amplitude continued to decrease and reached a level approximately 10fold lower at the end of the run. During the shutdown at the end of run $46 \mathrm{~A}$, noise measurements were taken at 56,50, and $40 \mathrm{MWt}$ and at $500 \mathrm{~kW}$. For all these, the amplitude remained small. 
Noise patterns for the two primary pumps at 50 MWt at the startup of run $46 \mathrm{~A}$ were essentially the same as those established from earlier 50-MWt operation. Although no earlier pump-noise data for $62.5 \mathrm{MWt}$ exist, the patterns established at $62.5 \mathrm{MWt}$ during run $46 \mathrm{~A}$ were consistent with data taken at $50 \mathrm{MWt}$.

The potential of using noise analysis for monitoring performance of the primary pumps was illustrated on September 29. On that date, the power demand for pump No. 1 gradually increased by $5 \mathrm{~kW}$, but no change in primary flow rate was indicated. Shortly thereafter, the audible noise from pump No. 1 was louder than usual. Notse recordings were taken and showed a change in the normal noise pattern. Over a period of about an hour, the noise pattern reverted to 1 ts usual form. Concurrently, audible noise and power demand returned to normal.

Figures 9-13 show plots of the noise recordings (in the plots "Grms" is the abbreviation for "gravity, root mean square"). Figure 9 shows plots taken with the MB accelerometer on primary pump No, 1 at 1500, from 0 to $20 \mathrm{kHz}$. During the time ( $230 \mathrm{~min})$ that the spectrum analyzer was being set up to record the data presented in Fig. 9, the pump noise was being observed on an oscilloscope; the noise appeared to decrease significantly from 1430 to 1500. Figure 10 shows data taken from 1515 to 1615 over the $0-100-\mathrm{Hz}$ range; the noise appears to progressively decrease. Figure 11 presents data similar to that of Fig. 9 but taken at 1615, when the noise level had decreased. Figure 12 gives similar data taken at 2210, and shows no significant difference from that of Fig. 11. For comparison, Fig. 13 shows the noise data during the initial rise to power for run $46 \mathrm{~A}$. A more detailed coverage of the noise analyses is given in Ref. 7 .

\section{PLANT OPERATION}

Surveillance of plant systems and components with the reactor operating at $62.5 \mathrm{MWt}$ in run 46A verified satisfactory performance as anticipated. The operating parameters in Table $\mathrm{V}$ are essentially the same as during initial 62.5-MWt operation in run 38A. The differences in heat balances 


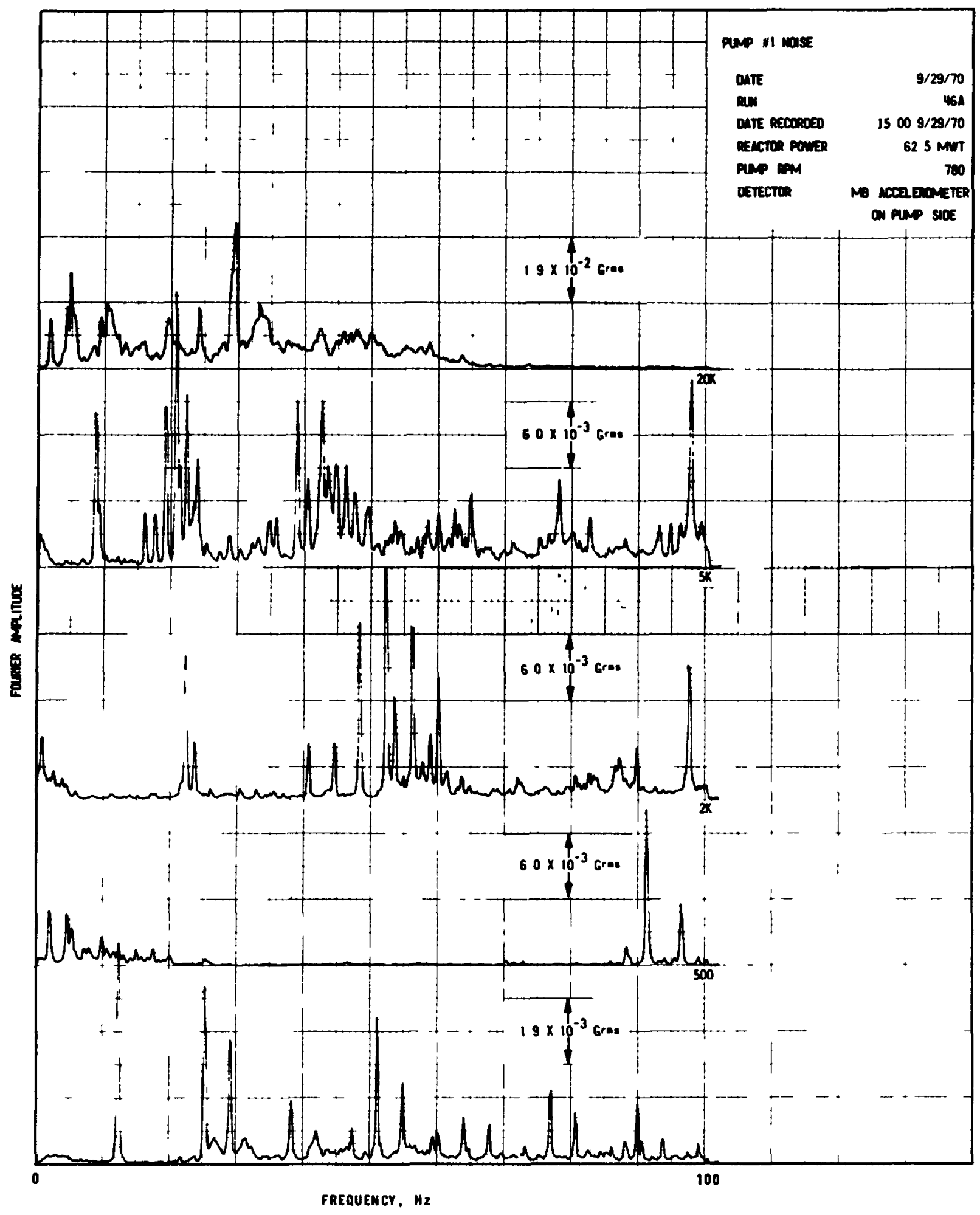

Fig. 9. Noise Recording for Pump No. I ( 0 to $20 \mathrm{kHz}$ ) at $1500,9 / 29 / 70$ 
PUMP \#I NOISE

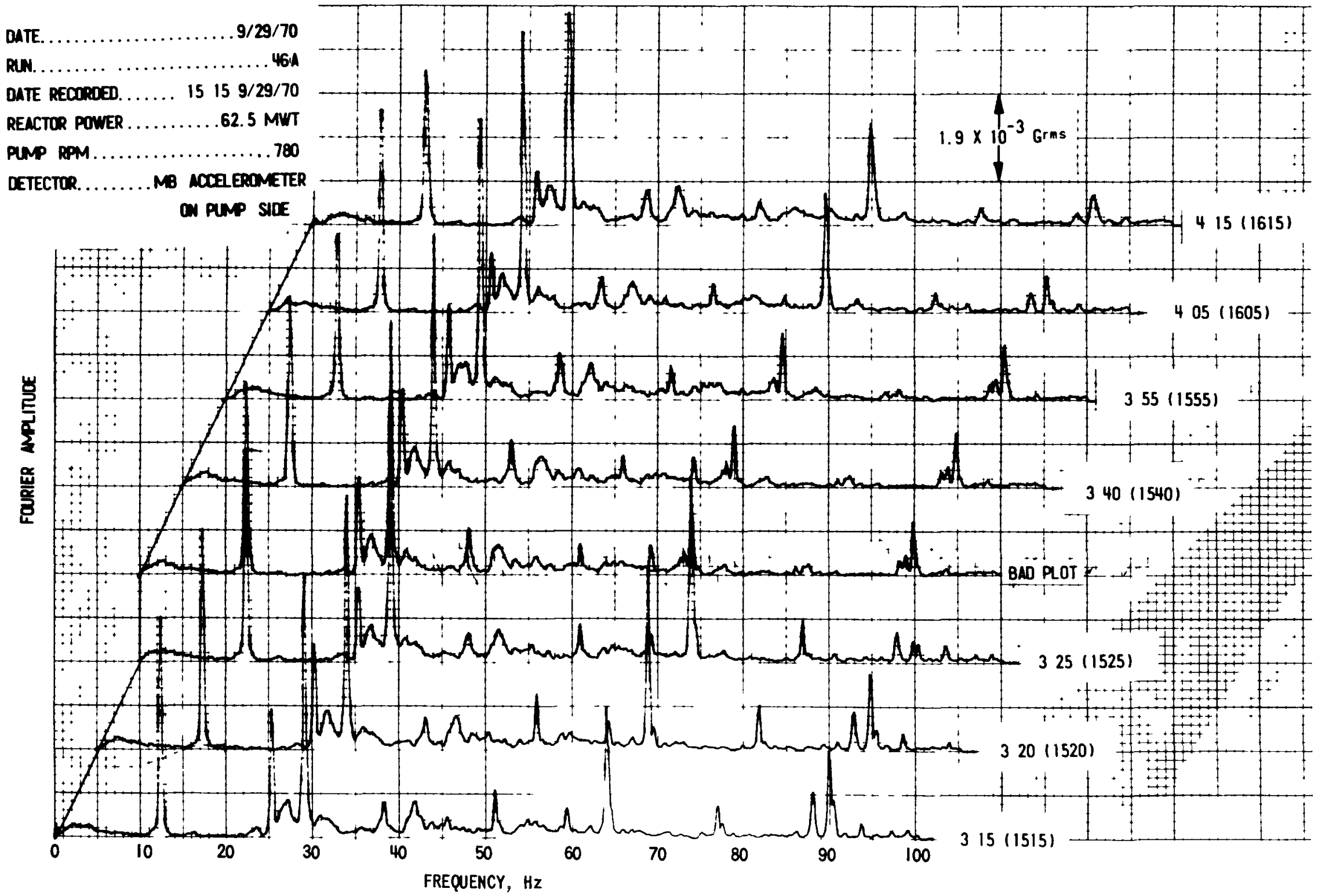

Fig. 10. Noise Recording for Pump No. 1 (0 to $100 \mathrm{~Hz}$ ) 1515 to $1615,9 / 29 / 70$ 


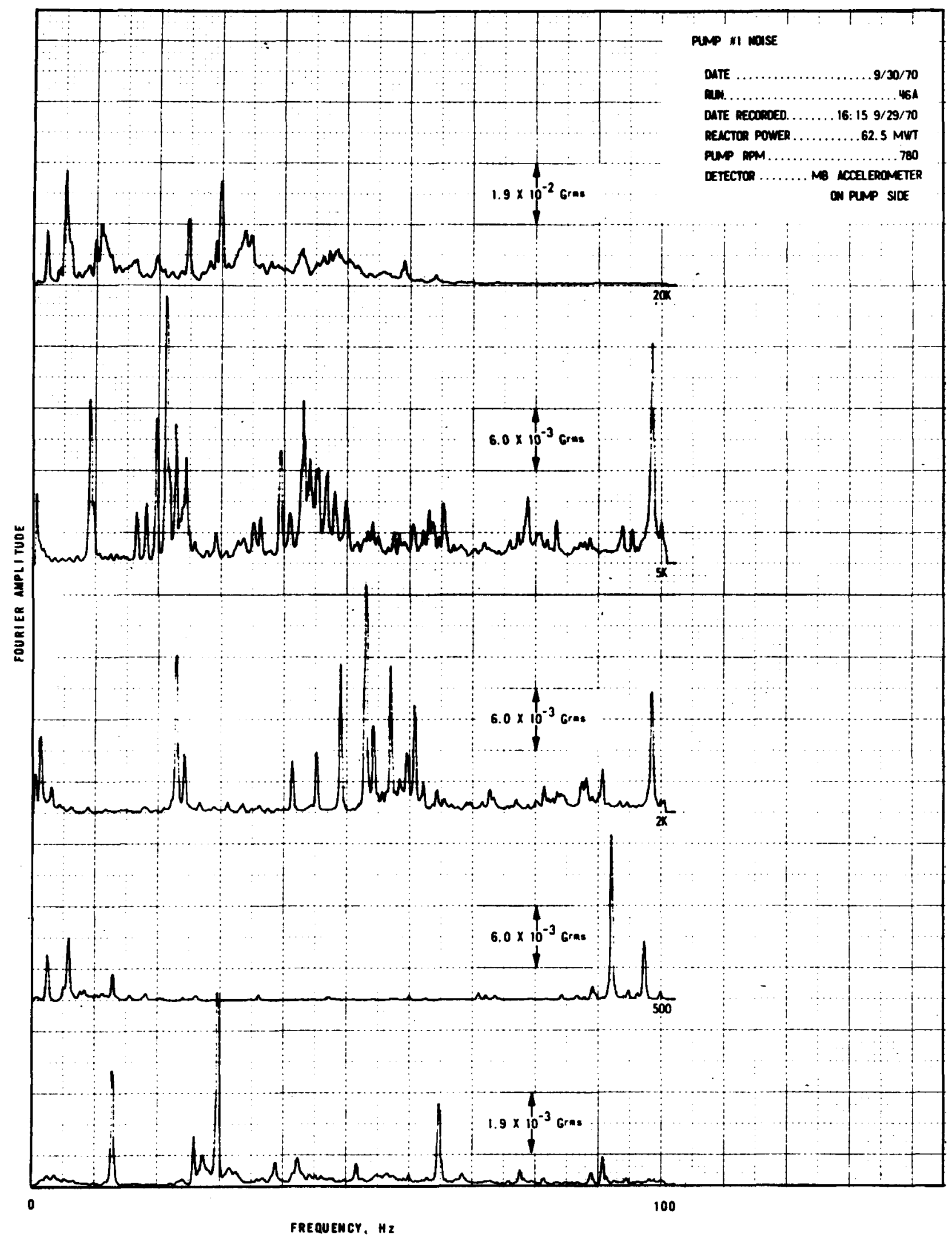

Fig. 11. Noise Recording for Pump No. 1 ( 0 to $20 \mathrm{kHz}$ ) at $1615,9 / 29 / 70$ 


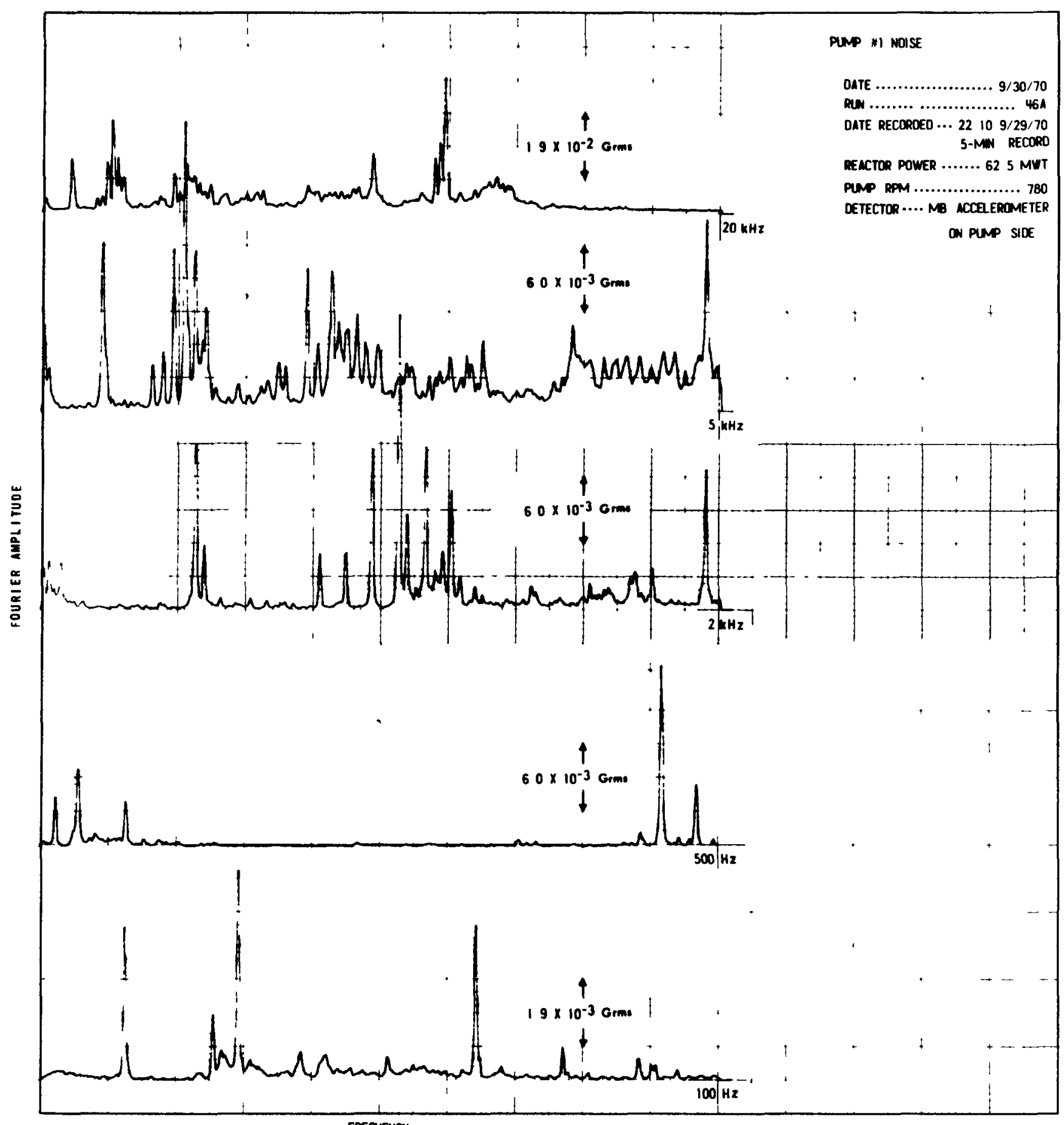

FREQUENCY

Fig, 12. Noise Recording for Pump No. 1 ( 0 to $20 \mathrm{kHz}$ ) at $2210,9 / 29 / 70$ 


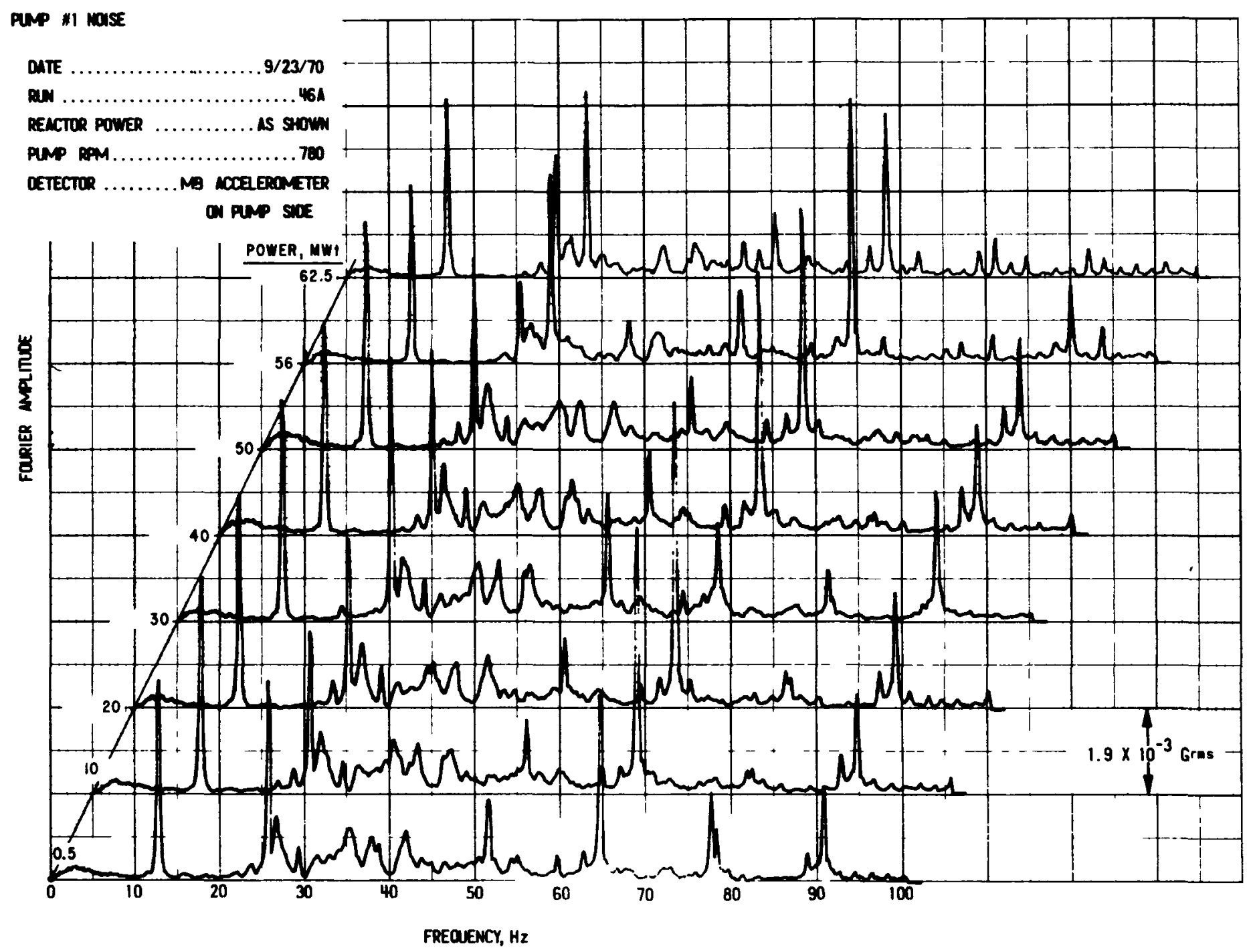

Fig. 13. Noise Recording for Pump No. 1 ( 0 to $100 \mathrm{~Hz}$ ) as a Function of Power, during Initial Rise to $62.5 \mathrm{MWt}$, Run 46A, 9/23/70 
TABLE V. Heat Balances and Component Parameters for Runs $38 \mathrm{~A}$ and $46 \mathrm{~A}$

\section{Parameter}

Primary-system Power, MWt Secondary-system Power, MWt Steam-system Power, MWt

Intermediate Heat Exchanger

Primary-sodium Flow Rate, 1000 1b/hr Primary-sodium Inlet Temp, ${ }^{\circ} \mathrm{F}$

Primary-sodium Outlet Temp, ${ }^{\circ} \mathrm{F}$

Secondary-sodium Flow Rate, $1000 \mathrm{lb} / \mathrm{hr}$

Secondary-sodium Inlet Temp, ${ }^{\circ} \mathrm{F}$

Secondary-sodium Outlet Temp, ${ }^{\circ} \mathrm{F}$

Steam Generator-Evaporators

Secondary-sodium Inlet Temp, ${ }^{\circ} \mathrm{F}$

Secondary-sodium outlet Temp, ${ }^{\circ} \mathrm{F}$

Feedwater Flow Rate, $1000 \mathrm{lb} / \mathrm{hr}$

Feedwater Inlet Temp--steam Drum, ${ }^{\circ} \mathrm{F}$

Steam Outlet Temp, ${ }^{\circ} \mathrm{F}$

Steam Generator--Superheaters

Secondary-sodium Inlet Temp, ${ }^{\circ} \mathrm{F}$

Secondary-sodium outlet Temp, ${ }^{\circ} \mathrm{F}$

Steam Flow Rate, $1000 \mathrm{lb} / \mathrm{hr}$

Steam Inlet Temp, ${ }^{\circ} \mathrm{F}$

Steam Outlet Temp, ${ }^{\circ} \mathrm{F}$

Turbine Generator

Steam Flow Rate, $1000 \mathrm{lb} / \mathrm{hr}$

Steam Temperature, ${ }^{\circ} \mathrm{F}$

Electrical Power, MWe

$a_{\text {From Ref. } 1 .}$

brom Ref. 2 .

$\frac{56 \mathrm{MWt}}{\text { Predicted }^{\mathrm{a}} \frac{\text { Measpred }}{\frac{\text { Run 38A }}{\text { Run 46A }}}} \frac{62.5 \mathrm{MWt}}{\text { Predicted }}{ }^{\mathrm{a}} \frac{\text { Measured }}{\text { Run 38A }} \frac{\text { Run 46A }}{\text { Run }}$

$\begin{array}{llllll}56 & 56.5 & 55.8 & 62.5 & 62.3 & 62.3 \\ 55.9 & 54.1 & 52.8 & 62.4 & 61.3 & 59.9 \\ 55.4 & 53.6 & 53.5 & 61.9 & 60.8 & 59.0\end{array}$

$\begin{array}{rrrrrr}3,820 & 3,860 & 3,810 & 3,820 & 3,810 & 3,810 \\ 864 & 864 & 864 & 883 & 883 & 883 \\ 700 & 700 & 700 & 700 & 700 & 700 \\ 2,240 & 2,230 & 2,200 & 2,380 & 2,360 & 2,360 \\ 584 & 588 & 588 & 585 & 586 & 588 \\ 862 & 858 & 857 & 879 & 872 & 873\end{array}$

$\begin{array}{llllll}791 & 788 & 785 & 803 & 800 & 802 \\ 580 & 582 & 588 & 582 & 581 & 586 \\ 245 & 244 & 240 & 270 & 265 & 260 \\ 549 & 559 & 550 & 549 & 560 & 550 \\ 579 & 580 & 583 & 579 & 580 & 582\end{array}$

$\begin{array}{llllll}858 & 857 & 850 & 875 & 870 & 865 \\ 791 & 788 & 785 & 803 & 800 & 802 \\ 225 & 224 & 220 & 250 & 250 & 241 \\ 578 & 580^{\mathrm{C}} & 583 & 578 & 580 & 582 \\ 811 & 807 & 808 & 820 & 819 & 817\end{array}$

$\begin{array}{cccccc}146 & 148^{\mathrm{d}} & 142 & 162 & 170 & 166 \\ 811 & 807 & 808 & 820 & 819 & 817 \\ 16.8 & 16.5 & 16.3 & 18.7 & 18.5 & 18.2\end{array}$

$c^{c}$ Value previously reported in Ref. 2 as $559^{\circ}$ due to typographical error.

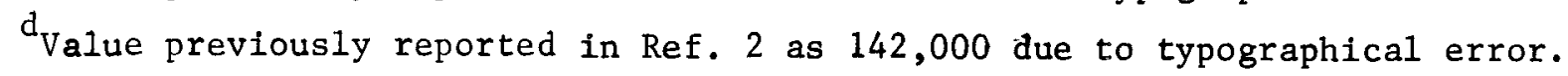


as measured in the primary and secondary sodium and the steam systems were greater during run $46 \mathrm{~A}$ than during 38A; the discrepancy is again believed to be due to inaccuracy in temperature measurements.

\section{A. Sodium Temperatures}

The increase in power from $50 \mathrm{MWt}$ to $62.5 \mathrm{MWt}$ caused additional temperature stratification in the primary-system bulk sodium. This was expected, however, because earlier observations had indicated that stratification increases in accordance with reactor power. The effects of stratification in run $46 \mathrm{~A}$ were like those of run $38 \mathrm{~A}$. Again, temperatures near the surface increased with power and those at the bottom decreased. Other studies, unrelated to run 46A, have suggested that bulk sodium mixing does take place in the central region of the tank but is not significant at the upper and lowermost sections. To a large extent the increased temperature at the upper level of bulk sodium and the slight decrease at the lower level may be attributed to natural convection. The rate of temperature rise in the upper-level sodium increases as reactor power is increased. The maximum difference in bulk sodium temperature at $50 \mathrm{MWt}$ was $31^{\circ} \mathrm{F}$. A thermocouple near the primary-secondary heat exchanger and reactor outlet piping registered a maximum temperature of $761^{\circ} \mathrm{F}$ at $62.5 \mathrm{MWt}$. Readings from this instrument fluctuated slowly over a range of $20-25^{\circ} \mathrm{F}$, indicating that natural convection does occur in this section of the primary tank.

\section{B. Steam System}

A dynamic test of the steam-bypass system, condenser, and cooling tower was conducted during run $46 \mathrm{~A}$ to determine:

1. Performance of power-plant systems when incoming-line circuit breakers were tripped with the reactor in normal operation at $62.5 \mathrm{MWt}$;

2. Performance of these systems when the turbine-generator output breaker was tripped under the same conditions; and

3. Performance of the main cooling tower at maximum load. Operation at $62.5 \mathrm{MWt}$ during run $38 \mathrm{~A}$ had indicated unsatisfactory operation of the large steam-bypass valve. As a result, a new plug was 
installed and the automatic controller replaced. Valve operation during run $46 \mathrm{~A}$ was satisfactory.

When the incoming-line breakers were tripped, the large steam-bypass valve began opening in $2.3 \mathrm{sec}$, opened to $80 \%$ at $4.4 \mathrm{sec}$, and stabilized at $75 \%$ open. The steam pressure increased from 1264 to $1330 \mathrm{psig}$ in about $2.0 \mathrm{sec}$, began decreasing at $2.5 \mathrm{sec}$, and then stabilized at $1290 \mathrm{psig}$ at $8 \mathrm{sec}$.

By tripping of the generator output breaker, full plant steam load was placed on the steam-bypass system. The large steam-bypass valve began opening in $2.3 \mathrm{sec}$, opened to $90 \%$ at $4.5 \mathrm{sec}$, and stabilized at $80 \%$ open. The steam pressure increased from 1264 to 1332 psig in about $2.5 \mathrm{sec}$, began decreasing at $3.5 \mathrm{sec}$, and stabilized at $1296 \mathrm{psig}$ at $10 \mathrm{sec}$.

To observe cooling-tower performance, the full steam load was bypassed directly to the condenser for about 2 hr after the breaker tests. The performance was satisfactory under existing atmospheric conditions.

Acoustical measurements were taken in each of the two superheaters during the increase of power to $62.5 \mathrm{MWt}$ for run 46. The accelerometers used in these measurements were attached by magnets near the center of the superheaters on the shell surface.

The purpose of the monitoring was to obtain acoustic noise recordings of the noise generated in the superheaters during the increase in power. A primary objective was to attempt to obtain a flow-related characteristic noise spectrum, which could be used for reference in the analysis of future data that might be taken. The results are shown in Figs. 14 and 15, for the east and west superheaters, respectively. The data indicate a characteristic noise spectrum related to flow through the superheaters at higher flow rates. This spectrum begins to appear when flow through the superheater is about $1750 \mathrm{gpm}$ (the flow rate for $30 \mathrm{MWt}$ ) and grows in amplitude as flow rate increases for higher-power operation. The frequency range of this noise is about $1-2 \mathrm{kHz}$. Figures 14 and 15 show that the same general spectrum existed on both superheaters.

The spectrum was examined up to $4 \mathrm{kHz}$ at zero power and at varying power levels to $62.5 \mathrm{MWt}$. Above about $2 \mathrm{kHz}$ no characteristic noise was detected. Below about $1 \mathrm{kHz}$ no noise that could be correlated with flow through the superheaters was detected. The $60-\mathrm{Hz}$ noise level in the 


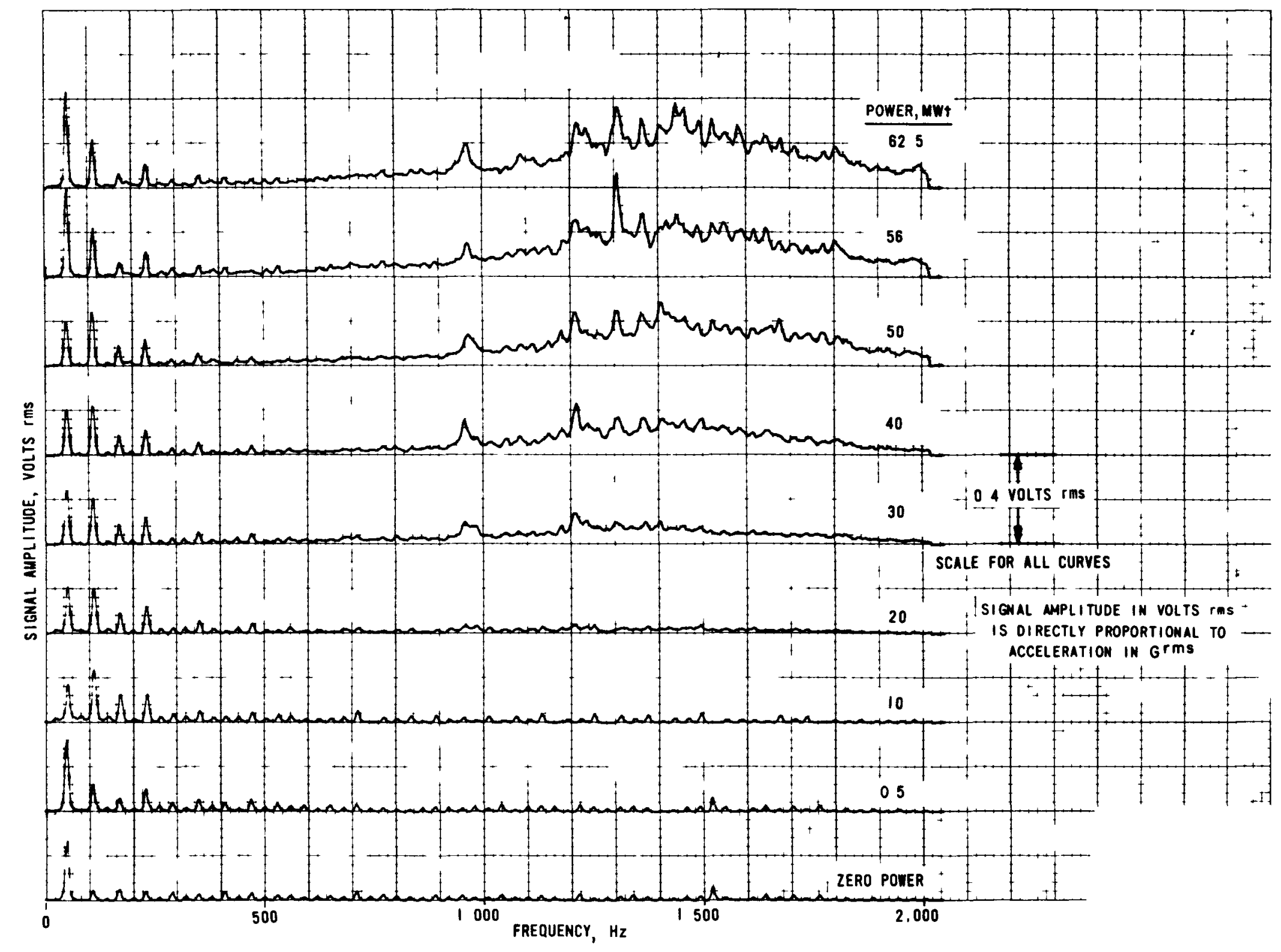

Fig. 14. Noise Spectrum as a Function of Power for East Superheater 


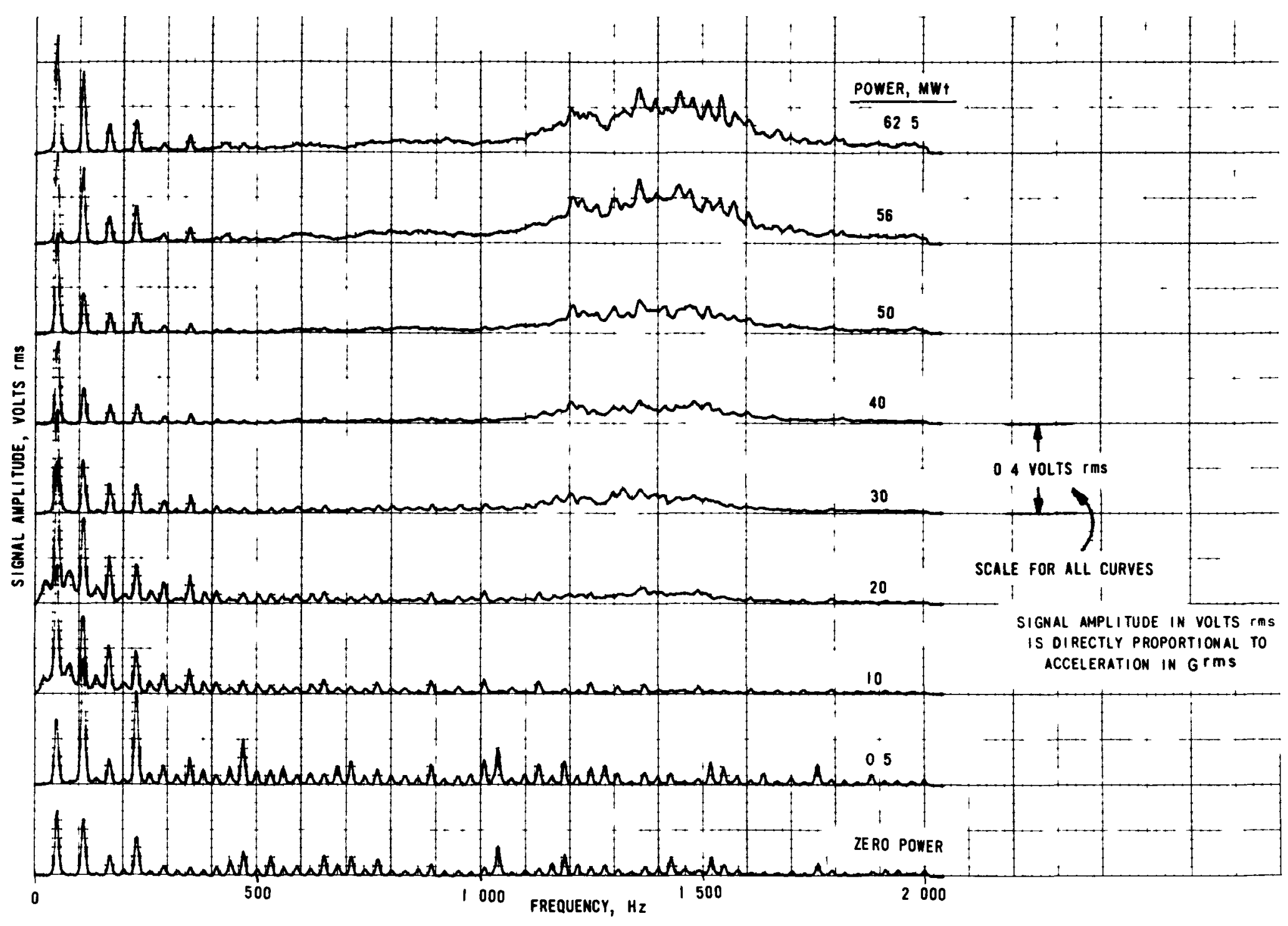

Fig. 15. Noise Spectrum as a Function of Power for West Superheater 
sodium-boiler building limfts low-frequency analysis. High levels of 60-Hz noise (and 60-Hz harmonics) were detected in the measuring system. However, the amplitude of these signals did not seem to be affected by changes in flow through the superheaters. In preparing the curves of Figs. 14 and 15 from the taped data, a high-pass filter was used to attenuate the $60-\mathrm{Hz}$ noise and harmonics.

The following equipment was used in obtaining the data: Gulton Model AQB 4971 accelerometers, an MB Electronics Model 9402216 line driver and Model N-400 charge amplifier, a Sangamo Model 3562 tape recorder, and a Spectral Dynamics Model SD301 spectrum analyzer. Comparing data collected during the run-46A startup with that collected during run $38 \mathrm{~A}$ was originally planned. However, no correlation exists. One reason for this difference is that the band widths of frequency response of the two measuring systems used differed. Earlier, the system-frequency response was limited to about $500 \mathrm{~Hz}$, whereas during run $46 \mathrm{~A}$ the response was up to $4 \mathrm{kHz}$.

As expected, either of the installed feedwater pumps was capable of carrying the total feedwater flow at 62.5-MWt operation. Performance of the turbine-driven pump is slightly better than that during run $38 \mathrm{~A}$. Repair of the check valve increased the apparent capacity of the turbinedriven pump enough to make it unnecessary to shut off the pump recirculation flow at full power.

The performance of the motor-driven pump remains the same as it was during run 38A. The pump is running wide open at $62.5 \mathrm{MWt}$. As previously discussed in Ref. 3, a recirculation-control valve will be installed on this pump to increase its capacity about $13 \%$.

The overload condition on the $480-V$ switchgear bus that would exist in the event of operation of a single power transformer has been eliminated by addition of cooling fans on each of the two 2000-kVA transformers. The fan-cooled capacity is $2300 \mathrm{kVA}$ each. Measured 480-V load at $62.5 \mathrm{MWt}$ operation is $2300 \mathrm{kVA}$.

The 480-V system load will be reduced further by the transfer of the Laboratory and office Building 752 feeder from the main switchgear to the APPR standby substation. This work is in process. 
A new $480-V$ substation has been purchased and the installation drawings are being prepared. This substation will remove all non-reactor-associated loads from the power-reactor plant switchgear.

The slight overload on the $2.4-\mathrm{kV}$ switchgear can be handled within the $10 \%$ continuous-overload capability of the transformer. Cooling fans to further increase the capability of these units will be ordered.

VI. OPERATING PROCEDURES AT $62.5 \mathrm{MWt}$

Before run 46A, the control-room copies of the Operating Manual had, with two exceptions, been revised to cover reactor and plant operation at $62.5 \mathrm{MWt}$. The two exceptions were the list of operating set-points (Appendix $G$ of the Manual) and the interlock check sheets (in Section II.A), which were written for a maximum power of $50 \mathrm{MWt}$. These sections were not revised after run 38A because it was not planned to return to $62.5 \mathrm{MWt}$ operation for about another year. The same was true of the operating data sheets. Therefore, in preparation for run 46A, a special operating procedure, No. SOP 102-70, was issued. This sOP contained the necessary revisions to the check sheets, data sheets, and set points to reflect the expected parameters based upon the previous operating experience at 62.5 MWt. Only minor changes were required to reflect the actual values obtained.

\section{CONCLUSION}

Operation of EBR-II at $62.5 \mathrm{MWt}$ during run $46 \mathrm{~A}$ was as expected. Continual operation at this power level is recommended.

\section{REFERENCES}

1. R. A. Cushman, Coordinator, Proposal for EBR-II Operation at 62.5 MWt, ANL/EBR-012 (August 1969).

2. R. A. Cushman, Coordinator, Operation of EBR-II at 62.5 MWt, An Evaluation of Plant and Reactor Data from Run 38A, ANL/EBR-013 (December 1969). 
3. Prospectus: Routine Operation of EBR-II at $62.5 \mathrm{MWt}$, ANL/EBR-019 (to be published).

4. H. A. Larson and I. A. Engen, Collection and Evaluation of Kinetics Data from Run 46A, ANL/EBR-028 (to be published).

5. R. W. Hyndman and R. B. Nicholson, The EBR-II Feedback Function, ANL-7478 (July 1968).

6. R. W. Hyndman, R. O. Haroldsen, and J. R. Karvinen, EBR-II Digital Data Acquisition System Study, ANL/EBR-001 (May 1969).

7. C. C. Price and J. R. Karvinen, EBR-II. Noise-signature Analysis During the First Half of Fiscal Year 1971, ANL/EBR-036 (to be published). 